\title{
A combined geochemical and hydrological approach for understanding
} macronutrient sources

\author{
Dan J Lapworth ${ }^{a^{*}}$, Daren C Gooddy ${ }^{\text {a }}$, Flo Kent ${ }^{\text {b }}$, Tim H E Heaton ${ }^{\text {c }}$, Steven J \\ Cole $^{\mathrm{d}}$, Debbie Allen ${ }^{\mathrm{a}}$ \\ ${ }^{a}$ British Geological Survey, Maclean Building, Wallingford, Oxfordshire, OX10 8BB, \\ UK \\ ${ }^{\mathrm{b}}$ Environment Agency, Orchard House, Endeavour Park, Addington, West Malling, \\ Kent, ME19 5SH, UK \\ ' NERC Isotope Geosciences Laboratory, Keyworth, Nottinghamshire, NG12 5GG, \\ UK \\ ${ }^{\mathrm{d}}$ Centre for Ecology \& Hydrology, Maclean Building, Wallingford, Oxfordshire, \\ OX10 8BB, UK \\ *Corresponding author, email: djla@ bgs.ac.uk, Tel: +44(0)1491692327, Fax: \\ $+44(0) 1491692345$
}

\section{Abstract}

This study employed complementary geochemical techniques and distributed hydrological modelling to investigate multiple sources of catchment macronutrients and characterise their changes in contrasting storm and baseflow conditions. This approach was demonstrated for the Beult catchment in the county of Kent (England), a designated Site of Special Scientific Interest (SSSI) indentified as failing to meet water quality standards for key nutrients under the Water Framework Directive. Significant changes in nutrient stoichiometry and bioavailability are observed for surface waters under contrasting flow regimes. Soluble reactive phosphorus (SRP) concentrations are approximately twice as high during baseflow compared to high flow, while the inverse is true for particulate, colloidal and dissolved hydrolysable phosphorus, dissolved organic carbon and nitrate. N:P ratios are lower during baseflow for most surface waters impacted by diffuse sources of pollution. Fluorescence indices of dissolved organic matter (DOM) show that waste water inputs may be locally important sources of more complex low molecular weight DOM, particularly during baseflow. Nitrate $\mathrm{N}$ and $\mathrm{O}$ isotope signatures, combined with other dissolved chemical tracer's, confirm the dominance of wastewater $\mathrm{N}$ inputs at sites downsteam of sewerage treatment works during baseflow, with a shift towards the soil $\mathrm{N}$ pool in surface waters across the catchment during high flow. Distributed hydrological modelling using the Grid-to-Grid model reveal areas with the greatest runoff also export higher $\mathrm{N}$ and $\mathrm{P}$ concentrations, and hence deliver a greater flux of macronutrients, while forested areas with low nutrient concentrations reduce runoff and nutrient fluxes. During periods of high runoff, nested sampling indicates that nutrient fluxes scale with catchment area. This combined approach enables a more thorough assessment of the macronutrient sources and dynamics, better informing management options in nutrient impacted catchments.

Keywords: Macronutrients; Beult Catchment; Source identification, Organic Matter Fluorescence Wastewater, Land Use, Grid-to-Grid Modelling 
45

46

47

\section{Introduction}

Carbon $(\mathrm{C})$, nitrogen $(\mathrm{N})$ and phosphorus $(\mathrm{P})$, often referred to as macronutrients, are essential components of a healthy aquatic ecosystem (Whitehead et al., 2012).

However, in recent decades anthropogenic inputs of macronutrients have caused perturbations to key macronutrient cycles, and led to widespread $\mathrm{N}$ and $\mathrm{P}$ pollution of aquatic systems (Heathwaite et al., 1996; Edwards and Withers, 2008; Neal et al., 2010). This is a global problem with implications for food production and security, water quality, as well as potential climate impacts (Meyer et al., 1999; Galloway et al., 2004).

In catchments with agricultural land use, diffuse sources usually dominate nutrient inputs to streams and groundwater, while in non-agricultural areas point sources such sewage/waste water treatment works (WWTWs) are important inputs (Johnes et al., 1996; Howarth et al., 1996; Jordan et al., 1997; Palmer-Felgate et al., 2010). The European Water Framework Directive (WFD 2000) requires that water bodies achieve good ecological and water quality status by 2015 . Therefore, there is a pressing need to understand nutrient sources, transport processes and attenuation mechanisms at the catchment scale.

Phosphorus (P) is an important nutrient in the environment: too little can inhibit plant growth whilst too much can lead to an excess which is subsequently stored in the soil.

This excess $\mathrm{P}$ can then be released into water bodies and may contribute to eutrophication and associated loss of ecological status (Jarvie et al., 2006, Holman et al., 2008, Withers and Jarvie, 2008). In a catchment, there are several different potential sources of dissolved $\mathrm{P}$ that can enter the river or groundwater body. Livestock farming has been shown to be an important source of nutrients from fertilisers, manure and feed concentrates $(\mathrm{P}$ and $\mathrm{N})$ in streams (Haygarth et al., 1998, 
70 Withers and Lord, 2002). Other major sources of nutrients are from point sources

71 such as slurry tanks (Gooddy et al., 2002), leaking septic tanks or drains (Palmer-

72 Felgate 2010) and particularly WWTWs which are a key source of $\mathrm{PO}_{4}$ and the

73 soluble polyphosphates used in detergents (Neal et al., 2010).

74 The bioavailability of nutrients is a key issue when considering the potential

89 Colloids are operationally defined as particles with diameters less than $10^{-5} \mathrm{~m}(10 \mathrm{~m})$

91 has been colloid bound P transport (e.g. Haygarth et al., 1997; Lapworth et al., 2011).

92 This is the transport of $\mathrm{P}$ bound to inorganic and organic particles which cover a large

93 range of sizes from large clay-humic-metal complexes to nanometre scale humic-like

94 compounds and carbonate, iron or silicate fractions. 
95 Increased anthropogenic inputs of $\mathrm{N}$ to the UK land surface, largely from fertiliser as well as some depositional sources, have resulted in widespread $\mathrm{N}$ pollution and the subsequent deterioration in the quality of both surface water and groundwater (e.g. Foster et al., 1986; MAFF 1993; Wang et al., 2012; Worrall et al., 2012). Nitrogen pollution in UK freshwaters is predominantly in the form of nitrate $\left(\mathrm{NO}_{3}\right)$ rather than nitrite $\left(\mathrm{NO}_{2}\right)$ or ammonium $\left(\mathrm{NH}_{4}\right)$ due to the predominantly oxidising conditions.

Nitrate concentrations in rivers often show a distinct seasonal variation, with peak concentrations in winter months and low concentrations in summer months (Johnes and Burt, 1993).

Dissolved organic matter (DOM) includes compounds such as carbohydrates and proteins, as well as humic substances including fulvic and humic acids (Thurman, 1985). Natural organic matter is derived from the decay of organic material from both plant and animal sources and almost half of all NOM fluoresces (Senesi, 1993).

Recent studies suggest that humic substances are a complex mixture of both microbial and plant biopolymers, with their various breakdown products, and cannot be classed as a distinct chemical structure (Kelleher and Simpson, 2006). In the natural environment DOM is often a complex mixture of many compounds, and as such is difficult and costly to characterise (Leenheer and Croue, 2003).

Much work has been undertaken in the last decades to quantify $\mathrm{C}, \mathrm{N}$ and $\mathrm{P}$ concentrations and fluxes, and the nature of nutrient transformations at the catchment and continental scale (Gruber and Galloway, 2008). However, there is still a major gap in current understanding of how nutrients are retained within complex landscapes and released to surface and groundwater bodies via surface and subsurface flow pathways. Most published studies to date have tended to focus only on one or two macronutrients; studies that combine all three nutrients are rare but are required to 
120 fully understand nutrient flux and processes within aquatic ecosystems (Whitehead et

121 al., 2012).

122 In this paper nutrient $(\mathrm{C}, \mathrm{N}$ and $\mathrm{P})$ concentrations, species, fluxes and associations

123 with colloidal and particulate matter are investigated within the Beult catchment of

124 southeast England, UK. The River Beult was chosen for this study as it has

125 'unfavourable status' as a result of failure to meet water quality targets, as well as

126 having other chemical and biological status concerns (Environment Agency, 2005). A

127 spatial survey of water quality across the catchment, for both groundwater and surface

128 water, was carried out during high flow (below a return period of 10 years for the

129 gauged site at Stile Bridge) and baseflow conditions within areas of contrasting land

130 use, giving a snapshot of the nutrient status and mobility across the catchment.

131 This study uses a range of complimentary techniques to investigate nutrient processes

132 within the catchment: (i) tangential flow fractionation (TFF) is used to investigate the

133 association of $\mathrm{P}$ and $\mathrm{C}$ to particulate, colloidal and dissolved phases ( $<10 \mathrm{KDa})$, (ii)

134 dissolved organic matter (DOM) is characterised using excitation-emission matrix

135 (EEM) fluorescence spectroscopy to investigate the nature of both labile and

136 recalcitrant DOM, (iii) $\mathrm{N}$ and $\mathrm{O}$ isotope techniques are used to investigate different

137 sources of $\mathrm{NO}_{3}$ within the catchment, (iv) coupled Grid-to-Grid distributed

138 hydrological modelling (Bell et al., 2009; Moore et al., 2006, 2007) and nutrient

139 chemistry data are used to explore spatial relationships between runoff and nutrient

140 flux. This type of novel multi-technique approach enables a more thorough

141 assessment of macronutrient sources and dynamics across the catchment, and so better

142 informs choices of management options in nutrient impacted catchments. 
143

\section{Study area}

144

\subsection{Location, hydrology and geology}

145 Figure 1 shows the location of the Beult catchment, simplified geology, and key

146 population centres. The River Beult rises near Ashford, Kent, and then flows North-

147 west through Headcorn, forming the largest tributary of the River Medway. The Beult

148 catchment is predominantly rural with scattered settlements: total urban coverage is

$149<1 \%$ of the total catchment area. Over $60 \%$ of the land-use is classified as agricultural

150 (CLC, 2000). During the 1930s, the lower section of the river between Smarden and

151 Yalding was straightened, widened and deepened to increase flow and drainage.

152 Today, water abstraction is largely for agricultural use, and therefore temporally

153 variable; surface water flow is increased in some reaches by effluent returns from

154 sewage treatment works.

155 Temporary weirs and sluices are used upstream of Stilebridge in the summer months

156 to maintain river stage and manage flow. Daily mean river flow for the Beult at Stile

157 Bridge, with a catchment area of $277 \mathrm{~km}^{2}\left(51^{\circ} 12^{\prime} 08.6584^{\prime \prime} \mathrm{N}, 000^{\circ} 30^{\prime} 54.4021^{\prime \prime} \mathrm{E}\right)$, is

158 shown in Figure 2a. The Weald Clay formation covers the vast majority of the

159 catchment area (approx. 80\%, see Figure 1) and very little natural storage exists

160 causing a flashy runoff regime. There are only minor groundwater inputs (baseflow)

161 from the Lower Greensand Group, resulting in a baseflow index of 0.2 at Stile Bridge

162 (NRFA, 2012).

163 The catchment is underlain by the Weald Clay formation, a thick $(110-270 \mathrm{~m})$ clay

164 and silty-clay within which are found outcrops of limestone and sand. The Lower

165 Greensand Group, comprising the Folkstone, Sandgate, Hythe and Atherfield Clay

166 formations, crop out along the northern margin of the catchment. The underlying 
167 Wealden Group, the Tunbridge Wells Sand formation, and Wadhurst Clay formation,

168 are located on the southern margin of the catchment (Figure 1). There are substantial

169 superficial deposits of alluvium, silty and sand gravel river terrace deposits adjacent

170 to the River Beult and its tributaries. For a detailed account of the geology of the

171 Maidstone area see Worssam (1963). Some spring flow issues from the Lower

172 Greensand Group, which is exposed along the northern margin of the catchments, and

173 also from the Tunbridge Wells Sand in the south.

\subsection{Water quality status of the Beult catchment}

175

176

177

178 resulted in the River Beult being designated as having 'unfavourable status' and

179 indentified as failing to meet quality standards under the WFD. High phosphate $\left(\mathrm{PO}_{4}\right)$

180 concentrations are the primary reason for the water quality failures, although nitrate

$181\left(\mathrm{NO}_{3}\right)$ concentrations are also high. The water quality at four sites, two downstream of

182 WWTWs and two impacted by other sources, have been monitored by the

183 Environment Agency (EA) between 2002 and 2008 for temporal trends in P and N

184 species. Average ammonium concentrations were low for all of the monitoring sites

$185(<0.5 \mathrm{mg} / \mathrm{L})$, with highest concentrations during low flow periods at all sites. Long-

186 term results for $\mathrm{NO}_{3}$ and $\mathrm{SRP}$ from this water quality monitoring are included in this

187 paper, and provide a context for the detailed follow-up work carried out during high

188 flow and baseflow conditions. 
189

190

191

192

193

194

195

196

197

198

199

200

201

202

203

204

205

206

207

\section{Methods}

\subsection{Sites and sampling}

Figure 1 shows the location of sites that are investigated as part of this study. A total of 20 sites from across the Beult catchment were sampled on two occasions, once during a period of high flow following intense rainfall in November 2008 and then during baseflow conditions in July 2009. The four EA monitoring sites that feature in this study are also shown. Table S1, supplementary information, shows details on site location, water type, and potential sources of nutrients.

Sites with potentially contrasting nutrient input sources were selected across the catchment based on land-use data and information on licensed discharges to the Beult.

Two surface water sites that were impacted by local WWTW discharges, Sutton Valence and Biddenden, were included in this study. Twelve sites were impacted by diffuse pollution from agricultural land-use, and two sites were selected where forest/woodland was the predominant land-use. Groundwater samples were collected at three locations from springs that issue at the contact between the Lower Greensand and the Weald Clay formations to the north of the catchment.

Groundwater sites were located to the north of the catchment. The sewage impacted sites were sampled downstream of discharges from the Sutton Valence WWTW, to the northwest of the catchment and downstream of Biddenden WWTW in its southern part. Samples upstream of the Sutton Valence WWTW were also collected for comparison. Agriculturally impacted sites, including field drains, were sampled from the River Sherway, a tributary of the River Beult. Two sites with predominantly forested land-use were located in the southern part of the catchment (see Figure 1), 
212

213

214 River samples were collected using a bucket; samples were taken from the centre of

and represent nutrient water quality for parts of the catchment that have been unaffected by either agricultural or wastewater inputs.

215 the flowing watercourse. Care was taken to ensure that the inlet did not disturb river

216 bed sediment during sampling. Groundwater samples were collected from springs

217 taking care to obtain samples from close to the inlet of collection tanks. On-site water

218 quality variables - dissolved oxygen (DO), $\mathrm{pH}$, redox potential temperature and

219 specific electrical conductance (SEC) - were measured and allowed to stabilise prior

220 to sampling where appropriate. $\mathrm{DO}, \mathrm{pH}$ and redox potential were measured in a flow-

221 through cell to obtain a representative field value. Alkalinity, referred to as $\mathrm{HCO}_{3}$ in

222 this paper, was determined in the field using $50 \mathrm{~mL}$ of sample by titration against

$2231.6 \mathrm{~N}$ sulphuric acid. The average values from two repeat titrations obtained in the

224 field were reported.

225 Samples for inorganic analysis were filtered in the field using $0.45 \mathrm{~m}$ cellulose nitrate

226 filters (Whatman ${ }^{\mathrm{TM}}$ ). Samples for DOC were filtered through a $0.45 \mu \mathrm{m}$ silver filters

227 (Millipore ${ }^{\mathrm{TM}}$ ) into sterile acid-washed glass containers and stored refrigerated in the

228 dark at $4^{\circ} \mathrm{C}$. A 2 litre unfiltered sample was collected and stored in dark plastic

229 bottles for analysis of the $\left.\quad{ }^{15} \mathrm{~N} /{ }^{14} \mathrm{~N}\right)$ and oxygen $\left({ }^{18} \mathrm{O} /{ }^{16} \mathrm{O}\right)$ isotope ratios of

230 nitrate.

231 Tangential Flow Fractionation

232 The use of Tangential-Flow Fractionation (TFF) has been investigated as an improved

233 method for fractionation of colloidal material (Guéguen et al., 2002; Morrison and

234 Benoit, 2004), as the tangential arrangement minimises the clogging at the membrane

235 surface. Although this is better than the classical method of filtration it does not avoid 
236 coagulation altogether. Previous work by Lapworth et al. (2009a and 2011) has

237 successfully used this method to investigate $\mathrm{P}$ and DOM association with different

238 size fractions in surface and groundwaters. The mass balance recovery of $\mathrm{P}$ was

239 calculated for all samples and was found to vary between 89 and $102 \%$ for $\mathrm{P}$, and was

240 slightly lower for DOC (72 to $86 \%$ ) presumably due to adsorption effects on the filter

241 membrane.

242 A Pellicon 2 Millipore $^{\mathrm{TM}}$ system was used for TFF with a range of large surface area

243 composite regenerated cellulose filters (nominal cut-off $10 \mathrm{kDa}$ ). A thorough protocol

244 for cleaning membranes is required (Guéguen et al., 2002), and was followed for this

245 work. All samples were pre-filtered prior to the TFF treatment to remove the larger

246 particulate matter using Whatman ${ }^{\circledR}$ glass fibre filters (nominal cut-off $2.7 \mathrm{~m}$ ). An

247 unfiltered sample was collected and stored in acid-washed glass bottles for analysis of

248 the whole sample. The full suite of filters were used in the initial round sampled under

249 high flow conditions to investigate the association of $\mathrm{P}$ with different sample

250 fractions. TFF using the nominal $10 \mathrm{KDa}$ filter, representing the truly dissolved phase,

251 was carried out for a subset of seven sites of contrasting land-use during both high

252 and low flow conditions.

$253 \quad 3.3$ Chemical analysis

$254 \quad$ 3.3.1 Inorganic Chemistry

255 Soluble reactive $\mathrm{P}$ (SRP) is a measure of the inorganic monomeric and easily-

256 hydrolysable phosphorus in the sample that has been filtered through a $0.45 \mathrm{~m}$ filter.

257 The SRP was determined colorimetrically using the method of Murphy and Riley

258 (1962) as modified by Neal et al. (2000). Total phosphorus (TP) is the combination of

259 total dissolved $\mathrm{P}$ and particulate P; this was measured by the method of Eisenreich et 
260

261 262

al. (1975). Total dissolved P (TDP) was determined using the method of Eisenreich et al. (1975) after filtration through a $0.45 \mathrm{~m}$ cellulose filter. The dissolved poorlyhydrolysable P (DHP) was calculated by difference. DP, the 'truly' dissolved P was isolated by TFF (10 KDa) and P determined using the Eisenreich et al. (1975) method. Colloidal P (CP) is operationally defined as $<0.45 \mathrm{~mm}$ and $>10 \mathrm{KDa}$ and was calculated by difference. Major anions $\left(\mathrm{NO}_{3}-\mathrm{N}, \mathrm{SO}_{4}\right.$ and $\left.\mathrm{Cl}\right)$ were analysed by Dionex TM liquid chromatography on filtered $(0.45 \mathrm{~m})$ samples. $\mathrm{HCO}_{3}, \mathrm{pH}$ and specific electrical conductance (SEC), and DO were determined in the field. $\mathrm{P}$ analysis was carried out within a week of sampling. A breakdown of $\mathrm{P}$ analysis used in this study is shown in the electronic supplementary information (Table S2). Limits of detection (LOD) for the P species were $7 \mathrm{~g} / \mathrm{L}$, LODs for the other analytes were as follows: $\mathrm{DOC}(0.5 \mathrm{mg} / \mathrm{L}), \mathrm{NO}_{3}-\mathrm{N} \mathrm{SO}_{4}$ and $\mathrm{Cl}(0.1 \mathrm{mg} / \mathrm{L}), \mathrm{HCO}_{3}(5 \mathrm{mg} / \mathrm{L})$.

\subsection{2 ${ }^{15} \mathrm{~N}$ and ${ }^{18} \mathrm{O} \mathrm{NO}_{3}$ analysis}

Nitrate was separated on anion resins and prepared as silver nitrate for analysis of ${ }^{15} \mathrm{~N} /{ }^{14} \mathrm{~N}$ and ${ }^{18} \mathrm{O} /{ }^{16} \mathrm{O}$ ratios by oxidative combustion and high-temperature pyrolysis, respectively, in Thermo Finnigan (Bremen, Germany) Flash 1112 and TC elemental analysers linked to a Delta+ XL mass spectrometer (Silva et al., 2000; Heaton et al., 2004). Isotope ratios were calculated as ${ }^{15} \mathrm{~N}$ values versus atmospheric $\mathrm{N}_{2}$ and ${ }^{18} \mathrm{O}$ values versus SMOW by comparison with IAEA standards N-1, N-2, and NO-3. Analytical precision (1 SD) was typically $<0.3 \%$ for ${ }^{15} \mathrm{~N}$ and $<0.6 \%$ for ${ }^{18} \mathrm{O}$.

\subsubsection{Organic matter characterisation}

Dissolved organic carbon (DOC) was measured using a Thermalox ${ }^{\mathrm{TM}} \mathrm{C}$ analyser after acidification and sparging, for both sampling rounds. In addition, organic matter 
284 fluorescence analysis was carried out to investigate the changes in dissolved organic 285 matter characteristics for selected sites in both sampling rounds following TFF $(<10$ $286 \mathrm{KDa})$.

287 Fluorescence spectroscopy has been used in many studies to characterise and 288 understand the sources of DOM in wastewater, surface water, groundwater and 289 terrestrial ecosystems (Baker, 2001, 2002; Lapworth et al., 2008, 2009a). Florescence 290 indices of DOM structure can provide information on key characteristics of DOM, 291 including the degree of humification, differentiating microbial and terrestrial sources 292 and the degree of structural conjugation and aromaticity (Zolsay et al., 1999;

293 McKnight et al., 2001).

294 All organic matter fluorescence analysis was carried out within a week of sampling. 295 Samples were stored in glass vials in the dark at $4^{\circ} \mathrm{C}$, and allowed to equilibrate to $29620^{\circ} \mathrm{C}$ prior to analysis. A Varian ${ }^{\mathrm{TM}}$ Cary Eclipse fluorescence spectrometer was used 297 for the fluorescence analysis. Excitation (Ex) wavelengths were set between 200 and $298400 \mathrm{~nm}$ with a $5 \mathrm{~nm}$ bandwidth and emission (Em) wavelength were set between 250 299 and $500 \mathrm{~nm}$ with a $2 \mathrm{~nm}$ bandwidth. The PMT voltage was set to $700 \mathrm{~V}$, and all 300 analysis was carried out in quartz vials with a path length of $1 \mathrm{~cm}$. All fluorescence 301 results are reported as an average of three repeat analyses, following blank 302 subtraction, and are presented in Raman units (R.U), normalised to the area under the 303 water Raman peak of Ultrapure water blanks at Ex350nm-Em397nm. Ultraviolet 304 absorbance measurements (A254nm) were carried out using a Varian (UV/visible) 305 spectrophotometer with a cell path of $1 \mathrm{~cm}$. Due to the high DOC ( $>5 \mathrm{mg} / \mathrm{L})$ in several 306 samples, dilution was required prior to fluorescence analysis to minimise absorbance 307 effects. Ultrapure water (ASTM type I reagent grade water, including a UV cracker) 308 was used for blank samples and to clean the quartz cell between samples. 
309 Three fluorescence organic matter (FOM) peaks within the EEM were used in this

310 study to compare intensities between sites, and sampling rounds: the fulvic-like (FA)

311 maxima (Ex330-340 nm, Em410-460 nm), the tryptophan-like (TRP) maxima

312 (Ex270nm-290nm, Em320-360nm) and the tyrosine-like (TY) maximum (Ex280nm-

313 270nm, Em294-302nm).

314 DOM characteristics were investigated through the use of three indices which have

315 been shown to relate to DOM structure: (i) the fluorescence index (FI) which is

316 commonly used to differentiate between terrestrial and microbial DOM sources

317 (McKnight et al., 2001), (ii) the humification index (HI), an indication of humicity,

318 and the condensing of fluorescing molecules (Zsolnay et al., 2001), (iii) the ratio of

319 two fluorescing components( ), representing recent labile OM, and representing

320 recalcitrant OM (Wilson and Xenopoulos., 2009; Parlanti et al., 2000). Data was

321 processed and indices calculated using R software (Lapworth and Kinniburgh, 2009).

\subsubsection{Mineralogy of suspended material}

323 X-ray diffraction (XRD) analysis was carried out on the fine fraction $(<2 \mathrm{~m})$ of

324 suspended material from five river samples, to characterise the mineralogy of this

325 material during the high flow survey. Analytical details and a summary table of

326 results are presented in the electronic supplementary information (Table S4).

$327 \quad 3.4$ Modelling runoff contributions across the catchment

328 The hydrological model used in this study was the Grid-to-Grid (G2G) Model (Bell et

329 al., 2009; Moore et al., 2006, 2007) which is a distributed grid-based rainfall-runoff

330 and routing model. It was developed as a means of modelling "everywhere" through

331 use of an area-wide approach that provides a natural way of addressing the ungauged

332 hydrological forecasting problem (i.e. locations where observed flows are not 
333 available). The distributed form of $\mathrm{G} 2 \mathrm{G}$ means that modelled flows are sensitive to

334 both the storm pattern and landscape shaping (through use of supporting spatial

335 datasets on terrain, soil/geology and land-cover), allowing unusual and extreme floods

336 to be better simulated through capturing the spatio-temporal evolution of river flows

337 across the model domain (Cole and Moore, 2009; Moore et al., 2006).

338 G2G is used operationally by the Flood Forecasting Centre (FFC) over England \&

339 Wales (Price et al., 2012) and the Scottish Flood Forecasting Service over Scotland

340 (Cranston et al., 2012) to support national Flood Guidance Statements. The FFC

341 countrywide configuration of the G2G Model, which runs on a $1 \mathrm{~km}$ grid with a 15

342 minute time-step, is used in this study. Gridded rainfall inputs to the model are formed

343 from the national network of EA tipping-bucket raingauges using multiquadric

344 surface fitting techniques (Moore et al., 2004; Cole and Moore, 2008) with automated

345 quality-control applied to the raingauge records (Howard et al., 2012).

346 In this study, the G2G Model has been used for the high flow monitoring survey.

347 Modelled flows have been extracted for grid-cells that correspond to the sample

348 locations and aggregated runoff volumes mapped across the domain to understand the

349 contribution to runoff and river flow from different parts of the Beult catchment.

3504 Results

3514.1 Historical changes in $\mathrm{PO}_{4}$ and $\mathrm{NO}_{3}$ between 2002 and 2008

352 Figure $2 b, 2 \mathrm{c}$ and $2 \mathrm{~d}$ show the temporal variations for $\mathrm{NO}_{3}-\mathrm{N}, \mathrm{SRP}-\mathrm{P}$ and molar $\mathrm{NP}$

353 at the four long-term monitoring sites within the Beult catchment. Two sites,

354 Biddenden and Sutton Valence-ds, are situated downstream of sewage treatment

355 inputs, and the other two sites, Romden Castle and Franks Bridge, do not have

356 significant upstream inputs from WWTW. 
357 Overall, the sites with WWTW inputs show higher mean SRP and $\mathrm{NO}_{3}$ concentrations 358 compared to sites without sewage inputs (see Figure $2 \mathrm{~b}$ and $2 \mathrm{c}$ ). Mean concentrations 359 of SRP g/L) and $\mathrm{NO}_{3}-\mathrm{N}(\mathrm{mg} / \mathrm{L})$ are 194 and 4.1 (Romden Castle), 227 and 7.4 360 (Franks Bridge), 639 and 12 (Biddenden-ds), 2034 and 19.7 (Sutton Valence-ds).

361 Mean concentrations for SRP and $\mathrm{NO}_{3}-\mathrm{N}$ at Sutton Valence-ds $>$ Biddenden-ds $>$

362 Franks Bridge $>$ Romden Castle, and sites downstream of WWTW discharges also

363 show the greatest variations (Figure $2 b-d)$.

364 The temporal trends for $\mathrm{NO}_{3}$ at the four long-term sites show less similarity based on 365 the historical time-series data between 2003 and 2008 (Figure 2b). At the Sutton

366 Valence site there is an overall increase in concentration, and the highest

367 concentrations are found in periods of low flow. At Franks Bridge and Biddenden, 368 while higher concentrations are also generally found during periods of low flow, and 369 when temperatures are higher, there is no obvious long-term change in mean annual 370 concentrations. At Romden Castle the temporal trend is less distinct, although there is 371 still considerable variation. At Romden Castle $\mathrm{NO}_{3}-\mathrm{N}$ concentrations are usually 372 below the EU drinking water limit of $11.3 \mathrm{mg} / \mathrm{L}$, while concentrations are consistently 373 above this water quality limit at the other sites.

374 The highest SRP concentrations (Figure 2c) are found during the periods of low flow 375 for all four sites. SRP-P concentrations at both WWTW impacted sites are regularly $376>1000 \mathrm{~g} / \mathrm{L}$ throughout the monitoring period. Figure $2 \mathrm{c}$ shows that there is a marked 377 decrease in SRP concentrations during spring 2004 at the Sutton Valence site, and 378 concentrations are now comparable with the Biddenden site, also downstream of a 379 WWTW. This sudden decrease in SRP concentration, and increase in N:P (Figure 2), 380 at Sutton Valance coincides with the use of reed-beds at this site as part of a water 381 treatment upgrade for P stripping. 
382

383

384

385

386

387

388

389

390

391

392

393

394

395

396

397

398

399

400

\subsection{Inorganic and nutrient chemistry}

Table 1 shows results for key nutrient species (DOC, $\mathrm{NO}_{3}$, TDP, SRP, DHP, TP, PP and ratios of $\mathrm{NO}_{3}: \mathrm{SRP}, \mathrm{SRP}: \mathrm{DHP}, \mathrm{NO}_{3}: \mathrm{Cl}$ TDP:Cl and SRP:Cl), for twenty sites across the Beult catchment. Results for both high flow (R1) and baseflow (R2) conditions are presented. All nitrate concentrations are expressed as $\mathrm{N}(\mathrm{mg} / \mathrm{L})$. Table

S3, electronic supplementary information, shows results for selected chemical parameters: $\mathrm{pH}, \mathrm{SEC}, \mathrm{HCO}_{3}, \mathrm{SO}_{4}, \mathrm{Cl}$. Figure 3 shows a ternary plot of key nutrients: DOC, SRP and $\mathrm{NO}_{3}$ for the different land-use types during both sampling rounds.

Analysis of variance (ANOVA) was used to explore the differences in variable concentrations ( $\mathrm{pH}, \mathrm{SEC}, \mathrm{HCO}_{3}, \mathrm{SO}_{4}, \mathrm{Cl}, \mathrm{DOC}, \mathrm{NO}_{3}, \mathrm{TDP}, \mathrm{SRP}$ and DHP) both between different types of water and between the two sampling rounds. Values were $\log _{(10)}$ transformed prior to ANOVA and results are shown in Table 2. Significant differences $(p<0.05)$ in all variables are found between the different sources (i.e. springs, field drains etc) as well as between the two sampling rounds with the exception of $\mathrm{SO}_{4}$ and DHP.

Groundwater from springs were found to have low concentrations of all $\mathrm{P}$ species, and high SEC and concentrations of $\mathrm{NO}_{3}$, compared to most surface waters and all waste water impacted sites. River samples from the two sites with dominantly forested landuse had the lowest average $\mathrm{SEC}, \mathrm{NO}_{3}$ and dissolved $\mathrm{P}$ concentrations of any group, including the springs. These two sites had contrasting PP concentrations, which accounts for a significant proportion $(>50 \%)$ of TP at both sites. Sites impacted by WWTW have $\mathrm{NO}_{3}$ concentrations $<10 \mathrm{mg} / \mathrm{L}$, and higher mean SRP and TDP concentrations compared to those sites where agricultural land-use dominated.

The SRP:DHP ratio was either greater for the baseflow survey or showed no change for the majority of sites, with the exception of Sutton Valance WWTW, Snapmill and 
407 Little Ommerden, two agriculturally impacted sites. In many cases the \%DHP was

408 twice as high during the high flow conditions compared to baseflow.

409 Considerably higher concentrations of $\mathrm{HCO}_{3}, \mathrm{Cl}$, and dissolved $\mathrm{P}$ species were found

410 during the baseflow survey for most surface waters. In contrast, $\mathrm{NO}_{3}, \mathrm{PP}, \mathrm{SO}_{4}$ and

411 DOC concentrations were lower at many sites during the baseflow survey. The

412 chemistry of the springs did not vary significantly during the study, with perhaps the

413 exception of moderately higher dissolved $\mathrm{P}, \mathrm{NO}_{3}$ and $\mathrm{DOC}$ during the high flow

414 survey at Pope Hall Spring (Table 1). The field drains had lower mean baseflow TDP,

415 SRP and DHP, similar DOC and higher $\mathrm{NO}_{3}$ concentrations, compared to the

416 agriculturally impacted rivers. However, PP concentrations were greater in the

417 agriculturally impacted rivers compared to the field drains during both surveys. Mean

$418 \mathrm{NO}_{3}$ data were similar for both groups if values from Little Southernden were

419 excluded from the analysis, which was not unreasonable as this site was clearly an

420 outlier having the highest concentrations across the whole survey $(51 \mathrm{mg} / \mathrm{L}-\mathrm{N})$ which

421 did not vary between the two surveys (Table 1).

422 Molar $\mathrm{NO}_{3}: \mathrm{SRP}$ ratios showed considerable variation between sites and between

423 survey (Table 1). In the high flow survey $\mathrm{NO}_{3}: \mathrm{SRP}$ ratios were found to be greatest

424 for springs $>$ field drains $>$ forested $>$ Agriculturally impacted $>$ WWTW impacted, while

425 in the baseflow survey WWTW $>$ Agriculturally impacted sites. $\mathrm{NO}_{3}$ :SRP ratios for

426 springs and sites that were impacted by WWTW showed the least change between the

427 two surveys, while agriculturally impacted sites, field drains and forested sites

428 showed the greatest changes with significantly lower ratios $(\mathrm{p}<0.001)$ during the

429 baseflow survey. This is due to a combination of both lower $\mathrm{NO}_{3}$ and higher SRP

430 concentrations during baseflow. The results from the two surveys suggest that the

431 long-term trends of lower $\mathrm{NO}_{3}$ :SRP ratios during periods of low flow compared to 
432 high flow (see Figure 2) represent processes that are occurring more widely across the 433 catchment.

434 The results from the two surveys are summarised in Figure 3 using a ternary plot of 435 DOC, $\mathrm{NO}_{3}$ and SRP. This illustrates several key results: (i) the change in nutrient 436 stoichiometry in surface waters due to inputs from diffuse agricultural land use and 437 WWTW point sources, (ii) the changes in nutrient stoichiometry in WWTW and 438 agriculturally impacted surface waters during contrasting flow conditions, (iii) the 439 relative stability of end members from groundwater, and particularly forested sub440 catchments.

\section{$441 \quad 4.3 \quad$ Colloidal and particulate $P$}

442 Figure 4 summarises the changes in $\mathrm{P}$ composition (PP, CP and DP) for six sites

443 between sampling rounds. Overall, the spring sample (Knowle Game Farm) showed 444 no significant changes in DP between the two surveys. The proportion and concentration of PP and CP was greater for most of the river sites (Sherway Bridge,

446 Franks Bridge and the Sutton Valance sites) during the high flow conditions (Figure 447 4a). DP concentrations and proportions were significantly higher during the baseflow 448 survey (Figure 4b), accounting for more than 50\% TP at all sites.

449 Colloidal P was found to be an important proportion of TP at the Field Drain site and 450 the site upstream of the WWTW, which showed the highest concentration of TP as 451 well as DP of any site, even during baseflow. There were dramatic changes in P 452 composition at the Sutton Valence site, downstream of WWTW inputs, during 453 baseflow. At this location, there appears to be a significant source of $\mathrm{P}$ upstream of 454 the WWTW, which the treated effluent was actually diluting during both surveys. The 455 concentration of WWTW SRP-P inputs was significantly lower during the high flow 
456 conditions (260 g/L compared to $928 \mathrm{~g} / \mathrm{L}$ ), presumably due to dilution from rainfall

457 (Table 1). The downstream composition at Sutton Valence is clearly dominated by the

458 WWTW inputs during baseflow conditions (Figure 4b), due to very low natural river

459 flow. The similarities in inorganic chemistry are noticeable during the baseflow

460 survey (see Table 1).

461 XRD analysis indicates that the suspended sediment samples have similar

462 mineralogies with major amounts of quartz, minor illite/smectite, 'kaolin' (one of the

463 kaolin group minerals including halloysite, kaolinite etc.) and 'mica' (undifferentiated

464 mica species possibly including muscovite, biotite, illite) and trace amounts of K-

465 feldspar and calcite (Table S4). There was no evidence of calcite in the field drain

466 sample.

\subsection{Fluorescence DOM characteristics}

Table 3 shows the results for selected dissolved organic matter indices $(\mathrm{TFF}<10$

$\mathrm{KDa}$ ), for six sites sampled during both surveys. The spring site showed no significant

changes in DOM character for the two surveys, indicative of a stable structural

composition of DOM, even during extreme rainfall events. The other sites showed

marked decreases in FA-like, TRP-like, TY-like fluorescence and HI during the

baseflow survey. This shows the relatively high concentrations of both bioavailable

(TRP and TY-like) and more recalcitrant (FA-like) DOM from the rapid overland

inputs from the soil zone during high flow conditions.

For the river samples, the marked difference in HI between the two surveys suggests

contrasting sources of DOM, with lower structural complexity during baseflow

conditions compared to high flow conditions, suggesting more recalcitrant sources of

DOM. The average FI of 1.56 is strongly indicative of terrestrially derived fulvic-like 
480 DOM (McKnight et al., 2001), while the consistently higher FI's during the baseflow 481 survey does perhaps suggest a larger proportion of microbial DOM during this period.

482 In addition, the higher at the spring site, and upstream and downstream of the

483 WWTW during the baseflow survey, also suggests a shift in DOM character to be 484 more autochthonous, from in-situ microbially derived sources (Table 3 ). The shift in 485 FI downstream of the WWTW, and consistent signature in this reach irrespective of 486 flow conditions, perhaps indicates a consistent input of microbial derived DOM from 487 the WWTW.

\section{$4.5{ }^{15} \mathrm{~N}$ and ${ }^{18} \mathrm{O}$ isotopes of $\mathrm{NO}_{3}$}

489 Figure 5a shows a cross plot of ${ }^{15} \mathrm{~N}$ and ${ }^{18} \mathrm{O}$ for $\mathrm{NO}_{3}$ in a spring, four agriculturally 490 impacted sites, two sites impacted by WWTW as well as the two WWTW discharge 491 waters. The WWTW discharge was only sampled during baseflow conditions. A cross 492 plot for ${ }^{15} \mathrm{~N}$ and $\mathrm{NO}_{3}$ for the same samples is shown in Figure 5b. Open symbols are 493 results from the baseflow survey, filled symbols results from the high flow survey.

494 The isotopic composition of nitrate at the spring site (Knowle Game Farm) showed 495 little change between the high flow and baseflow surveys. The average ${ }^{15} \mathrm{~N}$ value of 496 about $+4.9 \%$ is typical for UK groundwater (Heaton et al., 2005); and the average $497{ }^{18} \mathrm{O}$ value of $+2.9 \%$ exactly matches the value which would be expected for 498 bacterially-produced nitrate if one third of its oxygen is derived from water oxygen 499 (Knowle Game Farm spring water ${ }^{18} \mathrm{O}=-7 \%$ ), and two thirds is from atmospheric

$500 \mathrm{O}_{2}(+24 \%$; Kendall et al., 2007). The nitrate in the spring water is ultimately derived 501 from soils in the recharge area, and we would expect soil-derived nitrate in the 502 catchment to have broadly similar values. 
503 In contrast, samples of discharge from the two WWTW (which were only sampled

504 during the baseflow survey) have both higher ${ }^{15} \mathrm{~N}(+12.0$ and $+17.6 \%)$ and slightly

505 higher ${ }^{18} \mathrm{O}$ values $(+6.1$ and $+7.7 \%$ ). These values conform to data published for

506 discharge from other sewage treatment works (Anisfeld et al., 2007; Vane et al.,

507 2007), where preferential removal of the lighter ${ }^{14} \mathrm{~N}$ and ${ }^{16} \mathrm{O}$ molecules during

508 ammonia volatilisation or denitrification result in elevated ${ }^{15} \mathrm{~N}$ and ${ }^{18} \mathrm{O}$ values in

509 residual nitrate in the discharge. Elevated ${ }^{18} \mathrm{O}$ values may also be found in fertilizer

510 nitrate and in rainfall (though the latter can be excluded from consideration here by its

511 low concentration), but these sources tend to have low ${ }^{15} \mathrm{~N}$ values (Curtis et al., 2012;

512 Heaton et al., 2012)

513

$514{ }^{15} \mathrm{~N}$ and ${ }^{18} \mathrm{O}$ values for nitrate in most of the river waters fall within the range

515 encompassed by groundwater or soil-derived nitrate and WWTW nitrate sources

516 (Figure 5a). For the agriculturally impacted river sites it is evident that whilst there

517 were large differences between their nitrate concentrations in high flow and baseflow

518 periods, there was little difference in their isotope compositions. Differences were

519 found, however, for the WWTW impacted sites. During baseflow the nitrate isotope

520 compositions and concentrations of the sites downstream of the WWTWs are similar

521 to those of the WWTW discharge, confirming the dominance of this source during

522 baseflow. This association is absent during high flow, however, where lower ${ }^{15} \mathrm{~N}$ and

$523{ }^{18} \mathrm{O}$ values for sites downstream of the WWTWs suggest a greater proportion of soil-

524 derived nitrate. 
525

526

527

528

529

530

531

532

533

534

535

536

537

538

539

540

541

542

543

544

545

546

547

548

549

4.6 Mapping runoff and nutrient flux in the Buelt during the high flow survey

Hydrographs of the G2G modelled flow during the high flow survey period are presented in Figure 6 for selected sample sites. Gauged river flows for the Beult at Romden Castle are also provided for comparison. Since these observations were not used in the G2G model configuration they provide an independent assessment of the ungauged performance of G2G. The good agreement at Romden Castle during this period gives confidence that $\mathrm{G} 2 \mathrm{G}$ may provide meaningful flow estimates at other ungauged sample locations, particularly in terms of timing of flow peaks.

To aid understanding of the rainfall dynamics and resulting model response, catchment average rainfall and modelled soil moisture deficit (SMD) are also shown for the Romden Castle catchment (top plots, Figure 6). This identifies two distinct rainfall periods which correspond to the two observed flow peaks at Romden Castle and are marked in Figure 6. The first period is a single storm with estimated catchment average rainfall of $6.8 \mathrm{~mm}$ in 4 hours (average $1.7 \mathrm{~mm} / \mathrm{hr}$ ). The second period is longer and consists of three individual rainfall storms crossing the catchment which are generally less intense than the first period and give an estimated catchment average rainfall of $20.2 \mathrm{~mm}$ in 18 hours (average $1.1 \mathrm{~mm} / \mathrm{hr}$ ).

Maps of the time-averaged runoff ratio (runoff divided by rainfall) for each grid square derived from G2G modelling over the two storm events are shown in Figure 7 along with flux results for DOC, SRP and $\mathrm{NO}_{3}$. The spatial heterogeneity in $\mathrm{G} 2 \mathrm{G}$ runoff ratio provides an insight into the runoff generation across the catchment and is a reflection of the following model processes and datasets that support the $\mathrm{G} 2 \mathrm{G}$ formulation: (i) geology - moderate permeability of the sand formations in the southwest increases recharge and lowers runoff relative to the impermeable clay that dominates elsewhere (see Figure 1); (ii) soil HOST (Hydrology of Soil Type) class 
550 (Boorman et al., 1995) - mainly HOST class 25 overlies the impermeable clays which

551 enhances runoff, a small area of class 18 to the southwest with lower runoff, and class

5529 in lower reaches where groundwater frequently rises to within $40 \mathrm{~cm}$ of the surface;

553 (iii) Slope - increased runoff from steep slopes, particularly the steep scarp slope to

554 the northeast (see Figure 1); and (iv) capturing the antecedent soil moisture conditions

555 through the continual water accounting of the model. The relationship between

556 modelled flux and catchment area for DOC, $\mathrm{NO}_{3}-\mathrm{N}, \mathrm{SRP}$ and DHP are shown in

$557 \quad$ Figure 8.

5585 Discussion

$559 \quad 5.1 \quad$ Macronutrient sources and concentrations

560 Streams draining forested parts of the catchment, while only representing a low

561 proportion of total land-use $(<10 \%)$, provide the lowest concentrations of $\mathrm{P}$ and $\mathrm{N}$

562 inputs to the Beult. These sites did not exceed $\mathrm{NO}_{3}-\mathrm{N}$ or SRP-P water quality criteria

$563(11.3 \mathrm{mg} / \mathrm{L}$ and $100 \mathrm{~g} / \mathrm{L})$ for samples collected as part of this study. All the other

564 surface water sites in this study exceeded the SRP quality limit on at least one

565 occasion.

566 Groundwater sources were shown to provide a stable and low input of $\mathrm{P}$ and $\mathrm{C}$ within

567 the Beult catchment, but have consistently high $\mathrm{NO}_{3}$ concentrations. Groundwater

568 DOM fluorescence characteristics are consistent with other UK groundwater areas

569 with agricultural land-use (Lapworth et al., 2008; 2009). These are due to a

570 combination of factors: the relatively conservative transport of $\mathrm{NO}_{3}$ in groundwater,

571 the attenuation of $\mathrm{PO}_{4}$ in the soil and aquifer, and the microbial breakdown of DOM

572 in the soil and unsaturated zone and their long groundwater residence times compared

573 to other waters. While the groundwater contribution to river flow in the Beult is low 
$574(\mathrm{BFI}=0.2)$, the high concentrations of $\mathrm{NO}_{3}-\mathrm{N}(\mathrm{ca} .15 \mathrm{mg} / \mathrm{L})$ and high bioavailability

575 of groundwater P (largely SRP) suggests that groundwater inputs may be ecologically

576 significant, particularly during baseflow (Holman et al., 2008; Lapworth et al., 2011).

577 The nutrient composition of field drains is comparable with that of agriculturally

578 impacted rivers, into which they drain. These can be characterised as having, on

579 average, high concentrations of DOC ( $>15 \mathrm{mg} / \mathrm{L}), \mathrm{NO}_{3}-\mathrm{N}(>8 \mathrm{mg} / \mathrm{L})$ and $\mathrm{TP}(>400$

$580 \mathrm{~g} / \mathrm{L})$ during high flow, and much lower DOC (ca.10mg/L) and $\mathrm{NO}_{3}-\mathrm{N}(<1 \mathrm{mg} / \mathrm{L})$

581 during baseflow (excluding the anomalously high result from site 7). The shift in HI

582 in the surface waters shows that there is an important change in DOM character as

583 well as the abundance during contrasting flow conditions (Conran et al., 1999; Hood

584 et al., 2006). Under high flow, the surface waters of the Beult catchment are enriched

585 with a DOM of higher complexity as well as more abundant sources of bioavailable

$586 \mathrm{C}$, in the form of proteins, due to $\mathrm{C}$ export from the dominantly agricultural land-use

587 (Conran et al., 1999). The values (ca. 0.6) are consistent with other studies for

588 catchments with a high proportion of agricultural land-use (Wilson and Xenopoulos

589 2009).

590 SRP concentrations were noticeably less for the majority of field drain sites during the

591 baseflow survey (see Table 1), while they were greater for the agriculturally impacted

592 rivers. This suggests either (i) greater potential for $\mathrm{P}$ attenuation or a greater

593 proportion of shallow groundwater in field drain sources during baseflow, or (ii)

594 perhaps other important sources of SRP within the agriculturally dominated

595 catchment such as septic tanks (Palmer-Felgate et al., 2010). In-stream and hyporheic

596 zone uptake during baseflow conditions has been widely reported as an important

597 mechanism for P attenuation in surface waters (Mulholland et al., 1997; Jarvie et al.,

598 2006). River CP and PP concentrations and proportions were found to be greater 
599

600

601

602

603

604

605

606

607

608

609

610

611

612

613

614

615

616

617

618

619 particularly during baseflow (Imai et al., 2002).

620 Nitrate $\mathrm{N}$ and $\mathrm{O}$ isotopes signatures, combined with other chemical tracers (e.g. $\mathrm{NO}_{3}$,

621 SRP, Cl), confirm the dominance of WWTW N inputs at sites down-steam of

622 WWTW during baseflow (Curt et al., 2004). During high flow the nitrate isotope 
623 signature is shifted towards the soil $\mathrm{N}$ pool for all surface water sites, suggesting that

624 this, i.e. diffuse agricultural sources, is the dominant source $\mathrm{N}$ across the catchment

625 during these conditions (Neal et al., 2008).

626 Sites that were impacted by diffuse pollution from agriculture showed no net change

627 in ${ }^{15} \mathrm{~N}$ during contrasting flow conditions, with the exception of one site upstream of

628 Sutton Valence which is shifted to higher values (in excess of 17) during baseflow.

629 This illustrates two processes: (i) a relatively stable $\mathrm{N}$ source from agricultural

630 catchments, probably derived from the soil $\mathrm{N}$ pool, and (ii) the importance of point

631 sources of $\mathrm{N}$, in this case perhaps indicative of a manure source of $\mathrm{N}$ (Wassenaar,

632 1995; Choi et al., 2007). This could be from a dairy farm upstream and in close

633 proximity to the site. The combined uses of geochemistry and isotopes have helped

634 identify the different $\mathrm{N}$ pools, and the complex temporal dynamics and relative

635 dominance of these pools originating from different sources within the catchment.

$636 \quad 5.2$ Spatial variations in runoff and nutrient fluxes

637 Modelled runoff ratio across the catchment shows a large degree of spatial

638 heterogeneity for the high flow survey periods (Figure 7). The southwest of the

639 catchment shows a lower runoff ratio as well as significantly lower nutrient

640 concentrations and fluxes. This is a result of the soil, geological and topographical

641 controls on modelled runoff as well as the wooded land-use. These contrast with the

642 higher runoff and nutrient concentrations and fluxes in the centre and north of the

643 catchment, which are hotspots for nutrient export to the Beult. There is a consistent

644 relationship between $\mathrm{DOC}, \mathrm{NO}_{3}-\mathrm{N}$ and SRP fluxes at six selected sample sites during

645 the first event (see Figures 7a, c and e), and it is clear from Figure 8 (filled circles)

646 that these fluxes scale linearly with catchment size. Linear regression using data from 
647 the first event give coefficient of determination values between 0.995-0.985 for the

648 six flux/catchment area relationships shown in Figure 8. The strong relationships

649 found between all chemical fluxes and catchment size is a surprising result given the

650 potential errors associated with the modelling, sampling and analysis, but perhaps

651 provides a measure of confidence in the point flow estimates generated from the G2G

652 hydrological model. The relationship is poorer, as would be expected, for smaller

653 catchments and lower fluxes, due to larger uncertainties in the modelling. Given the

654 high flow/runoff conditions, this suggests that at the selected sample sites the nutrient

655 fluxes from this event are dominated by diffuse surface runoff sources, which are

656 evenly distributed across these sub-catchments and mask out any point source inputs.

657 The response to the second larger event (see Figure 6) is different, both in terms of

658 spatial flux patterns (see Figure 7) and the slope of flux-catchment size relationships

659 for all the nutrients based on three sample sites (Figure 8, hollow squares). An

660 exception is the conservative tracer $\mathrm{Cl}$ (Figure 8f) where the flux-catchment

661 relationship holds over both events as might be expected since catchment inputs are

662 dominated by rainfall sources (Figure 8f). These results could be explained in terms of

663 spatial differences in runoff ratio, with proportionally higher catchment runoff ratio

664 values as well as the magnitude of the second event. The higher magnitude event

665 mobilised greater DOC, TDP, SRP and particularly DHP (see Figure 8e) from the soil

666 for a given catchment area. In contrast, the more conservative (unbound) pollutant

$667 \mathrm{NO}_{3}$ shows a reduction in flux during the higher magnitude runoff event: this is most

668 likely due to the proportionally higher runoff ratio for this event and subcatchment

669 (see Figure 7b). This is also corroborated by the lower $\mathrm{NO}_{3}$ concentrations at these

670 sites and lower molar N:P ratios compared to the sites sampled during the first event

671 (see Table 1). The apparent loss of P flux downstream of site 9 (Figure 7f) may reflect 
672 the sample timing at site 9 and the fact that this site was sampled a day later on the

673 falling rather than rising hydrograph limb of the event as was the case for the two

674 downstream sites (see Figure 6). This is consistent with a "clockwise" solute

675 hysteresis effect during storm events where higher concentrations are observed during

676 the hydrograph rising limb of an event compared with those measured on the falling

677 limb (House and Warwick, 1998). This combined approach using a distributed

678 hydrological model and hydrochemical sampling shows good potential for evaluating

679 how different nutrient fluxes and pools respond temporally and spatially depending on

680 antecedent conditions and changes in catchment runoff characteristics. Such an

681 approach could help inform catchment-based water quality management plans for

682 reducing and understanding diffuse and point source pollution for the River Beult and

683 elsewhere, particularly as the G2G Model is already configured for England, Wales

684 and Scotland.

$685 \quad 5.3$ Macronutrient bioavailability under contrasting flow conditions

686 Within the Beult catchment there are significant changes in nutrient bioavailability

687 and stoichiometry for surface waters during baseflow and high flow conditions

688 following intense rainfall. SRP concentrations are approximately twice as high during

689 baseflow compared to high flow, while the inverse is true for PP, CP and DHP and

690 DOC and $\mathrm{NO}_{3}$.

691 Overall, N:P ratios are lower during baseflow for most surface waters that are

692 impacted by diffuse sources pollution (Table 1 and Figure 2). If $\mathrm{N}$ and $\mathrm{P}$ values are

693 normalised using $\mathrm{Cl}$, a conservative tracer with respect to the potential evaporation

694 and rainfall inputs to the hydrological model, there are no net changes in TDP and

695 SRP between contrasting flow conditions at sites impacted by diffuse sources of

696 pollution. However, sites impacted by WWTW are relatively enriched with respect to 
697 TDP and SRP during baseflow (Table 1), and all surface water sites show relative

698 depletion in $\mathrm{NO}_{3}$, so other wastewater sources upstream of these sites such as septic

699 tanks or dairy waste cannot be ruled out (Palmer-Felgate et al., 2010; Hively et al.,

700 2005). At some sites (Field Drain, Sutton Valence-us, Franks Bridge, Snoadhill Farm)

701 there are increases in SRP:Cl ratios during baseflow, possibly due to release of

702 surface bound $\mathrm{P}$ from sediments under higher $\mathrm{pH}$ and temperatures.

703 TFF results also show that there is a shift in the association of $\mathrm{P}$ from PP towards

704 'truly' dissolved forms and colloidal particles during low flow conditions. These are

705 more bioavailable forms of $\mathrm{P}$, and could also be in greater abundance due to the in-

706 stream breakdown of PP and CP, as well as other physical and chemical factors

707 (Bostrom 1988; Furumai et al., 1989). The higher $\mathrm{pH}$ and temperatures during

708 baseflow could facilitate the release of $\mathrm{PO}_{4}$ from sediments, both bed sediments and

709 suspended particulate and colloidal matter, due to increased completion for binding

710 sites on ferric complexes between hydroxyl and $\mathrm{PO}_{4}$ ions (Kim et al., 2003; Abrams

711 and Jarrell, 1995).

712 The low flow rates could also result in changes in bioavailable $\mathrm{P}$ within the water

713 column, shifting the N:P ratio and potential for eutrophication. Cyclical periods of

714 high flow will be important in replenishing nutrient sources within river networks,

715 sustaining the cycle of bioavailable P release and inputs to the catchment. They will

716 also be important in transferring nutrients from zones of excess to zones of relative

717 depletion. Autotrophic growth, and the potential deterioration in ecological status, is

718 likely to be limited by $\mathrm{N}$ availability during baseflow, which could partly account for

719 the relative enrichment in SRP and TDP in surface waters in this period.

720 There is a complex interaction between river sediments, which are largely composed

721 of illite/smectite, kaolin and mica (Table S4, electronic supplementary information), 
722

723

724

725

726

727

728

730

731

732

733

734

735

736

737

738

739

740

741

742

743

744

745

746

and DOM. This is controlled by $\mathrm{pH}$ and major ion chemistry (Gu et al., 1994). At

lower $\mathrm{pH}$ there is greater adsorption to clay surfaces by fulvic and humic acids,

particularly of higher molecular weight (MW) fractions, and $\mathrm{PO}_{4}$ has been shown to

inhibit the adsorption of low MW DOM fractions due to competition with surface

ligand exchange and electrostatic interactions (Hur and Schlautman, 2004).

The change in the DOM character within receiving rivers is partly due to inputs of

lower MW hydrophilic acids from WWTW sources (Imai et al., 2002). The interplay

between these multiple factors, different sources of $\mathrm{C}$ (natural and anthropogenic),

and the combined effect of higher $\mathrm{pH}$ and higher $\mathrm{PO}_{4}$, are all likely to contribute to

the overall shift in DOM character during contrasting flow conditions within the

catchment (Hood et al., 2006). Immediately after periods of high flow, and

mobilisation of soil nutrient pools, and during baseflow when WWTW inputs are

proportionally greater, autotrophic growth may be stimulated, producing temporal

zones of more rapid biological growth (McClain et al., 2002; Merseburger et al., 2005).

As groundwater $\mathrm{NO}_{3}$ concentrations are high compared to surface waters, these results confirm that baseflow groundwater inputs are low for most sites impacted by diffuse nutrient sources, perhaps with the exception of inputs of shallow groundwater sources to field drains. However, this could in part be due to the relatively long residence time within the subsurface and does not rule out the possibility of increased $\mathrm{N}$ inputs in the future due to the delayed arrival of increased $\mathrm{NO}_{3}$ concentrations at the water table where unsaturated zones are deep or downward flow is slow (Wang et al., 2012).

As well as the obvious temporal variability in water quality due to changes in flow, longer term trends (Figure 2) show that water sources impacted by WWTW can have dramatic shifts in nutrient quality due to changes in the efficiency of $\mathrm{P}$ and $\mathrm{N}$ 
747

748

749

750

751

752

761 Overall, the nutrient chemistry within the Beult catchment is controlled by diffuse

762 exports from arable agricultural land-use, as well as point source pollution from

763 WWTW and dairy farms. Wooded areas provide relatively small areas of low nutrient

stripping (Neal et al., 2008). While over the same period, sites impacted by

predominantly diffuse sources have not shown any long-term changes in nutrient

chemistry. However, there is no simple or clear distinction between diffuse and point

sources of pollution within the catchment: the reality is more dynamic and complex.

For example, reaches with obvious point source inputs have been shown to be equally impacted by diffuse sources during high flow conditions.

\section{Summary and Conclusions}

The results from this catchment-wide study reflect the fact that the River Beult fails to meet water quality standards under the WFD. All surface waters in this study had SRP-P concentrations $>100 \mathrm{~g} / \mathrm{L}$ on at least one occasion. Average groundwater SRP-P concentrations were $36 \mathrm{~g} / \mathrm{L}$, almost three times the concentrations found in surface waters draining wooded areas. Groundwaters, and some field drains, had consistently high $\mathrm{NO}_{3}-\mathrm{N}$ concentrations, $>11.3 \mathrm{mg} / \mathrm{L}$, as did sites downstream of WWTW during baseflow.

764 input to the River Beult.

765 There were significant changes in nutrient bioavailability and stoichiometry for

766 surface waters during baseflow and high flow conditions following intense rainfall.

767 SRP concentrations were approximately twice as high during baseflow conditions

768 compared to high flow conditions, while the inverse is true for PP, CP and DHP and

769 DOC and $\mathrm{NO}_{3}$. N:P ratios are lower during baseflow for most surface waters that are

770 impacted by diffuse sources of pollution. $\mathrm{Cl}$ normalised values suggest that changes in 
$771 \mathrm{P}$ are largely due to evaporative/dilution effects in catchments impacted by diffuse

772 pollution, while those impacted by WWTW sources showed net enrichments in P

773 during baseflow.

774 The higher FI, and lower HI found at the site downstream of the WWTWs,

775 compared to the agriculturally impacted sites, also mean that WW inputs may be

776 locally important sources of more complex DOM, particularly during baseflow. This

777 is likely due to inputs of lower MW hydrophilic acids from WW sources.

$778 \mathrm{~N}$ and $\mathrm{O}$ isotopes signatures, combined with other chemical tracers (e.g. $\mathrm{NO}_{3}$ ),

779 confirm the dominance of WWTW N inputs at sites downsteam of WWTW during

780 baseflow conditions. During high flow the nitrate isotope signature is shifted towards

781 the soil $\mathrm{N}$ pool for all surface water sites, suggesting that diffuse sources of $\mathrm{N}$

782 dominate during these conditions.

783 The combined use of different methods: P speciation, TFF, organic matter florescence

784 and $\mathrm{N}$ and $\mathrm{O}$ isotope analysis of $\mathrm{NO}_{3}$ and distributed hydrological modelling using the

785 G2G model has helped to characterise the highly dynamic nature of nutrient sources,

786 pollution and bioavailability in this typical lowland clay catchment. Future

787 applications of ${ }^{18} \mathrm{O}-\mathrm{PO} 4$ methods (e.g. Li et al., 2011) may further our understanding

788 of $\mathrm{P}$ sources, fate and turnover within catchments. Given the dynamic nature of these

789 and other catchments, long-term high-resolution monitoring of nutrients within such

790 catchments (Neal et al., 2012) coupled with distributed hydrological modelling

791 appears to be a useful approach to understand changes in nutrient fluxes and process

792 within catchments.

\section{Acknowledgements}


794 The authors thank Peter Williams for carrying out chemical analysis and assisting

795 during sampling campaigns. Heather Wickham and Sarah Harman (CEH) are thanked

796 for carrying out P analysis. Simon Kemp (BGS) is thanked for carrying out

797 mineralogy analysis. The authors thank Marianne Stuart (BGS) and Bob Moore

798 (CEH) for reviewing the manuscript. This paper was also improved by the two

799 anonymous reviewers. The paper is published with the permission of the Executive

800 Director, British Geological Survey (NERC).

\section{References:}

802 Abrams, M.M., Jarrell, W.M., 1995. Soil-phosphorus as a potential non-point source

803 for elevated stream phosphorus levels. J. Environ. Qual. 24, 132-138.

804

805

806

807

808

809

810

811

812

813

814

815

816

817

818

819

820

821

822

823

824

825

826

827

828

829

830

831

832

833

834

Baker, A., 2002. Fluorescence properties of some farm wastes: Implications for water quality monitoring. Water Res. 36, 189-195.

Baker, A., Lamont-Black, J., 2001. Fluorescence of dissolved organic matter as a natural tracer of ground water. Ground Water 39, 745-750.

Boorman, D.B., Hollis, J.M., Lilly, A., 1995. Hydrology of soil types: a hydrologically-based classification of soil of the United Kingdom. Report No. 126, Institute of Hydrology, pp 137.

Bell, V.A, Kay, A.L., Jones, R.G., Moore, R.J, Reynard, N.S., 2009. Use of soil data in a grid-based hydrological model to estimate spatial variation in changing flood risk across the UK. J. Hydrol. 377, 335-350.

Bostrom, B., 1988 Relations between chemistry, microbial biomass and activity in sediments of a polluted vs.a nonpolluted eutrophic lake.Verh. Int. Ver. Limnol. 23, $451-459$.

Choi, W.J., Han, G.H., Lee, S.M., Yoon, K.S., Choi, S.M., Ro, H.M., 2007. Impact of land-use types on nitrate concentration and $\mathrm{d} 15 \mathrm{~N}$ in unconfined ground water in rural areas of Korea. Agric. Ecosyst. Environ. 120, 259-268.

Cole,S.J., Moore, R.J., 2009. Distributed hydrological modelling using weather radar in gauged and ungauged basins. Advances in Water Resources 32(7), 1107-1120.

Cole, S.J., Moore, R.J., 2008. Hydrological modelling using raingauge-and radarbased estimators of areal rainfall. J. Hydrol. 358(3-4), 159-181.

Conran, C.S., Piampiano, J.T., Patterson, H.H., 1999. Influence of land use and hydrology on exports of carbon and nitrogen in a Maine River Basin. J. Environ. Quality 28, 953-961. 
835

836

837

838

839

840

841

842

843

844

845

846

847

848

849

850

851

852

853

854

855

856

857

858

859

860

861

862

863

864

865

866

867

868

869

870

871

872

873

874

875

876

877

878

879

880

881

882

883

884

Corine Land Cover, 2000. European land use data http://www.eea.europa.eu/dataand-maps

Cranston, M., Maxey, R., Tavendale, A., Buchanan, P., Motion, A., Cole, S., Robson, A., Moore, R.J., Minett, A., 2012. Countrywide flood forecasting in Scotland: challenges for hydrometeorological model uncertainty and prediction. In: Weather Radar and Hydrology (ed. by R.J. Moore, S.J. Cole \& A.J. Illingworth) (Proc. Exeter Symp., April 2011), IAHS Publ. no. 351, 538-543, 2012.

Curt, M.D., Aguado, P., Sánchez, G., Bigeriego, M., Fernandéz, J., 2004. Nitrogen isotope ratios of synthetic and organic sources of nitrate water contamination in Spain. Water Air Soil Poll. 151, 135-142.

Curtis, C.J., Heaton, T.H.E., Simpson, G.L., Evans, C.D., Shilland, J. and Turner, S., 2012. Dominance of biologically produced nitrate in upland waters of Great Britain indicated by stable isotopes. Biogeochemistry, 11, 535-554.

Edwards, A.C., Withers, P.J.A., 2008. Transport and delivery of suspended solids, nitrogen and phosphorous from various sources to freshwaters in the UK. J. Hydrol. $350,144-153$.

Eisenreich, S.J., Bannerman, R.T., Armstrong, D.E., 1975. A simplified phosphorus analytical technique. Environ. Lett. 9, 45-53.

Environment Agency (EA)., 2005. Medway catchment abstraction management strategy. < http://publications.environment-agency.gov.uk/PDF/GESO0405BNZJ-EE.pdf $>$ last accessed February 2012.

Foster, S.S.D., Bridge, L.R., Geake, A.K., Lawrence, A.R., Parker, J.M., 1986. The Groundwater Nitrate Problem. BGS Hydrogeology Research Report 86/2.

Froelich, P.N., 1988. Kinetic control of dissolved phosphate in natural rivers and estuaries: A primer on the phosphate buffer mechanism. Limnol. Oceanogr. 33, 649668.

Furumai, H., Kondo, T., Ohgaki, S., 1989. Phosphorus exchange kinetics and exchangeable phosphorus forms in sediments. Water Res. 23, 685-691.

Galloway, J.N., Dentener, F.J., Capone, D.G., Boyer, E.W., Howarth, R.W., Seitzinger, S.P. et al., 2004. Nitrogen cycles: past, present and future. Biogeochem. $70,153-226$.

Gooddy, D.C., Clay, J.W., Bottrell, S.H., 2002. Redox-driven changes in pore-water chemistry of the Chalk unsaturated zone beneath unlined cattle slurry lagoons.

Applied Geochem. 17, 903-921.

Gruber, N., Galloway, J.N., 2008 An earth-system perspective of the global nitrogen cycle. Nature 451, 293-296. 
885 Gu, B., Schmitt, J., Chen, Z., Liang, L., McCarthy, J.F., 1994. Adsorption and

886 desorption of natural organic matter on iron oxide: mechanisms and models. Environ.

887 Sci. Tech. 28, 38-46.

888

889

890

891

892

893

894

895

896

897

898

899

900

901

902

903

904

905

906

907

908

909

910

911

912

913

914

915

916

917

918

919

920

921

922

923

924

925

926

927

928

929

930

931

932

933

934

Guéguen, C., Belin, C., Dominik, J., 2002. Organic colloid separation in contrasting aquatic environments with tangential flow filtration, Water Res. 36, 1677-1684.

Haygarth, P.M., Wood, F.L., Heathwaite, A.L., Butler, P.J., 2005. Phosphorus dynamics observed through increasing scales in a nested headwater-to-river channel study. Sci. Total Envion. 344: 83-106.

Haygarth, P.M., Warwick, M.S., House, W.A., 1997. Size distribution of colloidal molybdate reactive phosphorus in river waters and soil solution. Water Res. 31, 439448 .

Haygarth, P.M., Hepworth, L., Jarvis, S.C., 1998. Forms of phosphorus transfer in hydrological pathways from soil under grazed grassland. Eur. J. Soil Sci. 49:65- 72

Heathwaite, A.L., Johnes, P.J., Peters, N.E., 1996. Trends in nutrients and water quality. Hydrol. Proc. 10, 263-293.

Heaton, T.H.E., Wynn, P., Tye, A., 2004. Low ${ }^{15} \mathrm{~N} /{ }^{14} \mathrm{~N}$ ratios for nitrate in snow in the High Arctic $\left(79^{\circ} \mathrm{N}\right)$. Atmospheric Environ. 38, 5611-5621.

Heaton, T.H.E., Stuart, M.E., Sapiano, M. and Micallef Sultana, M.,2012. An isotope study of the sources of nitrate in Malta's groundwater. J. Hydrology, 414-415, 244254.

Heaton, T.H.E., Trick, J.K., Williams, G.M., 2005. Isotope and dissolved gas evidence for nitrogen attenuation in landfill leachate dispersing into a chalk aquifer. Applied Geochem 20, 933-945.

Hively, W.D., Bryant, R.B., Fahey, T.J., 2005. Phosphorus concentration in overland flow from diverse locations on a New York dairy farm. J. Env. Qual. 34, 1224-1233.

Holman, I.P., Whelan, M.J., Howden, N.J.K., Bellamy, P.H., Willby, N.J., RivasCasado, M., McConvey, P., 2008. Phosphorus in groundwater-an overlooked contributor to eutrophication? Hydrol. Proc. 22, 5121-5127.

Hood, E., Gooseff, M.N., Johnson, S.L., 2006. Changes in the character of stream water dissolved organic carbon during flushing in three small watersheds, Oregon. J. Geophys. Res. 111, GO1007, doi:10.1029/2005JG000082.

House, W.A., Warwick, M.S., 1998. Hysteresis of the solute concentration/discharge relationship in rivers during storms. Water Res. 32, 2279-2290.

Howard, P.J., Cole, S.J., Robson, A.J., Moore, R.J., 2012. Raingauge quality-control algorithms and the potential benefits for radar-based hydrological modelling. In: Moore RJ, Cole SJ, Illingworth AJ editors. Weather Radar and Hydrology (Proc. Exeter Symp., April 2011) IAHS Publ. no. 351; 219-224. 
935

936

937

938

939

940

941

942

943

944

945

946

947

948

949

950

951

952

953

954

955

956

957

958

959

960

961

962

963

964

965

966

967

968

969

970

971

972

973

974

975

976

977

978

979

980

981

982

983

Howarth, R.W., Billen, G., Swaney, D., Townsend, A., Jaworski, N., Lajtha, K. et al., 1996. Regional nitrogen budgets and riverine N \& P fluxes for the drainages to the North Atlantic Ocean: natural and human influences. Biogeochem. 35, 75-139.

Hur, J., Schlautman, M.A., 2004. Effects of $\mathrm{pH}$ and phosphate on the adsorptive fraction of purified Aldrich humic acid on kaolinite and hematite. J. Coll. Inter. Sci. 277, 264-270.

Imai, A., Fukushima, T., Matsushige, K., Kim, Y-H., Choi K., 2002. Characterization of dissolved organic matter in effluents from wastewater treatment plants. Water Res. $36,859-870$.

Jarvie, H.P., Neal, C., Withers, P.J.A., 2006. Sewage-effluent phosphorus: A greater risk to river eutrophication than agricultural phosphorus? Sci. Total Environ. 360, 246-253.

Johnes, P.J., Burt, T.P., 1993. Nitrate in surface waters T.P. Burt, A.L. Heathwaite, S.T. Trudgill (Eds.), Nitrate: processes, patterns and management, Wiley, Chichester, pp. $270-317$.

Johnes, P.J., 1996.Evaluation and management of the impact of land use change on the nitrogen and phosphorus loads delivered to surface waters: the export coefficient modelling approach. J. Hydrol. 183, 323-349.

Jordan, E.T., Correll, D.L., Weller, D.E., 1997. Relating nutrient discharges from watersheds to land use and streamflow variability. Water Resour. Res. 33(11), 257792590 .

Kim, L-H., Choi, E., Stenstrom, M.K., 2003. Sediment characteristics, phosphorus types and phosphorus release rates between river and lake sediments. Chemosphere $50,53-61$.

Lapworth, D.J., Gooddy, D.C., Allen, D., Old, G.H., 2009a. Understanding groundwater, surface water, and hyporheic zone biogeochemical processes in a Chalk catchment using fluorescence properties of dissolved and colloidal organic matter, J. Geophys. Res. 114, G00F02, doi:10.1029/2009JG000921.

Lapworth, D.J., Gooddy, D.G., Butcher, A., Morris, B., 2008 Tracing groundwater flow and sources of organic carbon in sandstone aquifers using fluorescence properties of dissolved organic matter (DOM), Applied Geochem. 23, 3384-3390.

Lapworth, D.J., Gooddy, D.G., Jarvie, H.P., 2011.Understanding phosphorus mobility and bioavailability in the hyporheic zone of a Chalk stream, J. Water Air and Soil Poll. 218, 213-226.

Lapworth, D.J., Kinniburgh, D.G., 2009b. An R Script for Visualising and Analysing Fluorescence Excitation-Emission Matrices (EEMs).Computers and Geoscience 30, 2160-2163. 
984 Leenheer, J.A., Croue, J.P., 2003. Characterizing aquatic dissolved organic matter.

985 Environ. Sci. Technol. 37, 18A-26A.

986

987

988

989

990

991

992

993

994

995

996

997

998

999

1000

1001

1002

1003

1004

1005

1006

1007

1008

1009

1010

1011

1012

1013

1014

1015

1016

1017

1018

1019

1020

1021

1022

1023

1024

1025

1026

1027

1028

1029

1030

1031

1032

Li, X., Wang, Y., Stern, J., Gu, B., 2011. Isotope evidence for the source and fate of phosphorous in Everglades wetland ecosystems. Applied Geochem. 26(5), 688-695.

MAFF, 1993. Solving the nitrate problem: progress in research and development (PB 1092). MAFF publications, Admail 6000, London SW1A 2XX.

McKnight, D.M., Boyer, E.W., Westerhoff, P.K., Doran, P.T., Kulbe, T., Andersen, D.T., 2001. Spectrofluorometric characterisation of dissolved organic matter for indication of precursor organic material and aromaticity. Limnol. Oceanog. 46, $38-$ 48.

McClain, M., Boyer, E.W., Dent, C.L., Regal, S.E., Grimm, N.B., Groffman, P.M. et al., 2003. Biogeochemical hot spots and hot moments at the interface of terrestrial and aquatic ecosystems. Ecosystems 6, 301-312.

Moore, R.J., Bell, V.A., Cole, S.J., Jones, D.A., 2007. Rainfall-runoff and other modelling for ungauged/low-benefit locations. Science Report - SC030227/SR1, Research Contractor: CEH Wallingford. Environment Agency, Bristol, UK, 249pp.

Moore, R.J., Cole, S.J., Bell, V.A., Jones, D.A., 2006. Issues in flood forecasting: ungauged basins, extreme floods and uncertainty. In: Frontiers in Flood Research (ed. by I. Tchiguirinskaia, K. N. N. Thein \& P. Hubert), 8th Kovacs Colloquium, UNESCO, Paris, June/July 2006, IAHS Publ. 305, 103-122.

Moore, R.J., Jones, A.E., Jones, D.A., Black, K.B., Bell, V.A., 2004. Weather radar for flood forecasting: some UK experiences. 6th Int. Symp. on Hydrological Applications of Weather Radar, 2-4 February 2004, Melbourne, Australia, 11pp.

Morrison, M.A., Benoit, G., 2004. Investigation of conventional membrane and tangential flow ultrafiltration artifacts and their application to the characterization of freshwater colloids. Environ. Sci. Tech. 38, 6817-6823.

Merseburger, G.C., Eugènia, M., Sabater, F., 2005. Net changes in nutrient concentrations below a point source input in two streams draining catchments with contrasting land uses. Sci. Total Environ. 347, 217-229.

Meyer, J.L., Sale, M.J., Mulholland, P.J., Poff, N.L., 1999. Impacts of climate change on aquatic ecosystem functioning and health. J. Am. Water Res. Assoc. 35, 13731386.

Murphy, J., Riley, J.P., 1967. A modified single solution method for the determination of phosphate in natural waters. Anal. Chim. Acta 27, 31-36.

Neal, C., Neal, M., Wickham, H., 2000. Phosphate measurements in natural waters: two examples of analytical problems associated with silica interference using phosphomolybdic acid methodologies. Sci. Total Environ. 251/252, 511-522. 
1034 Neal, C., Jarvie, H.P., Love, A., Neal, M., Wickham, H., Harman, S., 2008. Water

1035

1036

1037

1038

1039

1040

1041

1042

1043

1044

1045

1046

1047

1048

1049

1050

1051

1052

1053

1054

1055

1056

1057

1058

1059

1060

1061

1062

1063

1064

1065

1066

1067

1068

1069

1070

1071

1072

1073

1074

1075

1076

1077

1078

1079

1080

1081

1082

1083

quality along a river continuum subject to point and diffuse sources. J. Hydrol. 350, 156-165.

Neal, C., Jarvie, H.P., Withers, P.J.A., Whitton, B.A., Neal, M., 2010. The strategic significance of wastewater sources to pollutant phosphorus levels in English rivers and to environmental management for rural, agricultural and urban catchments. Sci. Total Environ. 408, 1485-1500.

Neal, C., Reynolds, B., Rowland, P., Norris, D., Kirchner, J.W., Neal, M., Sleep, D., Lawlor, A., Woods, C., Thacker, S., Guyatt, H., Vincent, C., Hockenhull, K., Wickham, H., Harman, S., Armstrong, L., 2012. High-frequency water quality time series in precipitation and streamflow: From fragmentary signals to scientific challenge. Sci Total Environ NRFA (National River Flow Archive). http://www.ceh.ac.uk/data/nrfa/index.html, last accessed on the 23rd March 2012.

Palmer-Felgate, E.J., Mortimer, R.J.G., Krom, M.D., Jarvie, H.P., 2010. Impact of point-source pollution on phosphorus and nitrogen cycling in stream-bed sediments. Environ. Sci. Tech. 44(3), 908-914.

Parlanti, E., Worz, K., Geoffroy, L., Lamotte, M., 2000. Dissolved organic matter spectroscopy as a tool to estimate biological activity in a coastal zone submitted to anthropogenic inputs. Org. Geochem. 31, 1765-1781.

Price, D., Hudson, K., Boyce, G., Schellekens, J., Moore, R.J., Clark, P., Harrison, T., Connolly, E., Pilling, C., 2012. Operational use of a grid-based model for flood forecasting. Water Manage. 165(2), 65-77.

R Development Core Team, 2012. The R foundation for statistical computing, Vienna University of Technology, Vienna, Austria.

Schelske, C.L., Rothman, E.D., Stoermer, E.F., Santiago, M.A., 1974. Responses of phosphorus limited Lake Michigan phytoplankton to factorial enrichments with nitrogen and phosphorus. Limnol. Oceanogr. 19:409-419.

Schindler, D.W., 1974. Eutrophication and recovery in experimental lakes:

Implications for lake management. Science 184:897-899.

Senesi, N., 1993. In: Organic substances in soil and water: natural constituents and their influences on contaminant behaviour; Bech, AJ, Jones, KC, Hayes, MBH, Mingelgrin, U, Eds.; The Royal Society of Chemistry: Cambridge p 74.

Stumm, W., 1977. Chemical interactions in particle separation. Environ. Sci. Tech. 11, 1066-1070.

Thurman, E.M., 1985. Organic geochemistry of natural waters. Martinus Nijhoff/Dr. W Junk Publishers, Boston.

Vane, C.H., Kim, A.W., McGowan, S., Leng, M.J., Heaton, T.H.E., Kendrick, C.P., Coombs, P., Yang, H., Swann, G.E.A., 2012. Sedimentary records of sewage 
1084

1085

1086

1087

1088

1089

1090

1091

1092

1093

1094

1095

1096

1097

1098

1099

1100

1101

1102

1103

1104

1105

1106

1107

1108

1109

1110

1111

1112

1113

1114

1115

1116

1117

1118

1119

1120

1121

1122

1123

1124

1125

1126

1127

1128

1129

1130

pollution using faecal markers in contrasting peri-urban shallow lakes. Sci. Total Environ. 409, 345-356.

Wang, L., Stuart, M.E., Bloomfield, J.P., Butcher, A.S., Gooddy, D.C., McKenzie, A.A. et al., 2012. Prediction of the arrival of peak nitrate concentrations at the water table at a regional scale in Great Britain. Hydrol. Proc. 26, 226-239.

Wassenaar, L.I., 1995. Evaluation of the origin and fate of nitrate in the Abbortsford Aquifer using the isotopes of $15 \mathrm{~N}$ and $18 \mathrm{O}$ in NO3-. Applied Geoch. 10, 391-405.

Water Framework Directive (WFD), Council of European Communities, 2000. Establishing a framework for community action in the field of water policy (WFD;2000/60/EC). Official Journal of EC L327, December.

Whitehead, P.G., Crossman, J., 2012. Macronutrient cycles and climate change: Key science areas and an international perspective. Sci. Total Environ. 434, 13-17.

Wilson, H.F., Xenopoulos, M.A., 2009. Effects of agricultural land use on the composition of fluvial dissolved organic matter. Nature Geo. 2, 37-41.

Withers, P.J.A., Jarvie, H.P., 2008. Delivery and cycling of phosphorus in rivers: A review. Sci. Total Environ. 400, 379-395.

Withers, P.J.A., Lord, E.I., 2002. Agricultural nutrient inputs to rivers and groundwaters in the UK: policy, environmental management and research needs. Sci. Total Environ. 282-283, 9-24.

Worssam, B.C., 1963. Geology of the country around Maidstone. Memoir of the British Geological Survey, Sheet 288, HMSO.

Worrall, F., Davies, H., Burt, T., Howden, N.J.K., Whelan, M.J., Bhogal, A., Lilly, A., 2012. The flux of dissolved nitrogen from the UK - Evaluating the role of soils and land use. Sci. Total Environ. 434,90-100.

Zolsay, A., Baigar, E., Jimenez, M., Stinweg, B., Saccomandi, F., 1999. Differentiating with fluorescence spectroscopy the sources of dissolved organic matter in soils subjected to drying. Chemosphere 38, 45-50.

\section{Table captions:}

Table 1. Summary of the nutrient chemistry for the Beult catchment

Table 2. Summary ANOVA table for selected chemical variables

Table 3. TFF and fluorescence results

\section{Figure captions:}

Figure 1. Location of study area, sampling sites, drainage, geology and main population centres. a) Geology, drainage network and centres of population within the 
1131 Beult catchment; b)Location of the Beult catchment (shown in bold) as part of the 1132 Medway catchment, Kent, UK . Site numbers refer to sites in Table 1. * EA water level and flow monitoring sites. Population centres: $a=C$ ranbrook, $b=$ Smarden, $\mathrm{c}=$ Staplehurst, $\mathrm{d}=$ Headcorn, $\mathrm{e}=$ Stilebridge. Drainage data courtesy of CEH (NERC). Sites 4, 5 and 11 are located on a small low order tributary of the River Beult.

Figure 2. Long-term flow and nutrient data: a) Daily mean flow between 2003 and 2010 at Stilebridge, the outlet of the Beult catchment, b) $\mathrm{NO}_{3}-\mathrm{N}$, c) SRP-P, d) Molar $\mathrm{N}: \mathrm{P}$ ratios. Red stars in Figure 2 a show sampling rounds.

1139 Figure 3. Ternary plot of DOC, SRP and $\mathrm{NO}_{3}$. Circles show results during the storm

1140 flow survey, triangles results from the baseflow survey.

1141 Figure 4. Phosphorus association with particulate, colloidal and dissolved fractions

1142 by TFF. a) storm flow results, b) baseflow results.

1143 Figure 5. Nitrate $\mathrm{N}$ and $\mathrm{O}$ isotope results. a) Nitrate ${ }^{15} \mathrm{~N}$ and ${ }^{18} \mathrm{O}$ cross plot, b) ${ }^{15} \mathrm{~N}$ 1144 vs $\mathrm{NO}_{3}-\mathrm{N}$ scatter plot. Filled symbols show results during storm flow conditions, 1145 open symbols show results during baseflow conditions. Numbers refer to sites, see 1146 Table 1. WW indicates sites that are impacted by wastewater sources, WWTW, 1147 discharge from wastewater treatment works.

1148 Figure 6. G2G modelled flow at selected gauged and ungauged sites across the study 1149 area during the high-flow survey. River flows for the Beult at Romden Castle are provided for comparison. Catchment average rainfall and modelled soil moisture deficit are shown for the Romden Castle catchment area (top plots). The two main rainfall/runoff events during this period are highlighted and used in Figure 7 and 8.

Figure 7. Time-averaged $\mathrm{G} 2 \mathrm{G}$ gridded runoff ratio and relationship to site nutrient flux during the storm flow survey a-b) DOC, c-d) $\mathrm{NO}_{3}-\mathrm{N}$, e-f) SRP. Left hand panels show results for the first storm event (21:00 08/11/08 - 01:00 09/11/08), and right hand panels for second event (07:00 10/11/08 - 01:00 11/11/08). Site numbers are shown in Figure 7 a (see Table 1 for details).

Figure 8. Scatter plots of nutrient flux and catchment area. a) DOC, b) SRP, c) TDP, 1160 square symbols are from the second runoff event. The red line shows a robust linear 1161 regression line for data from the first event. 

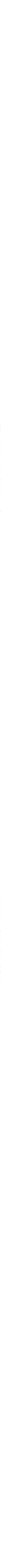


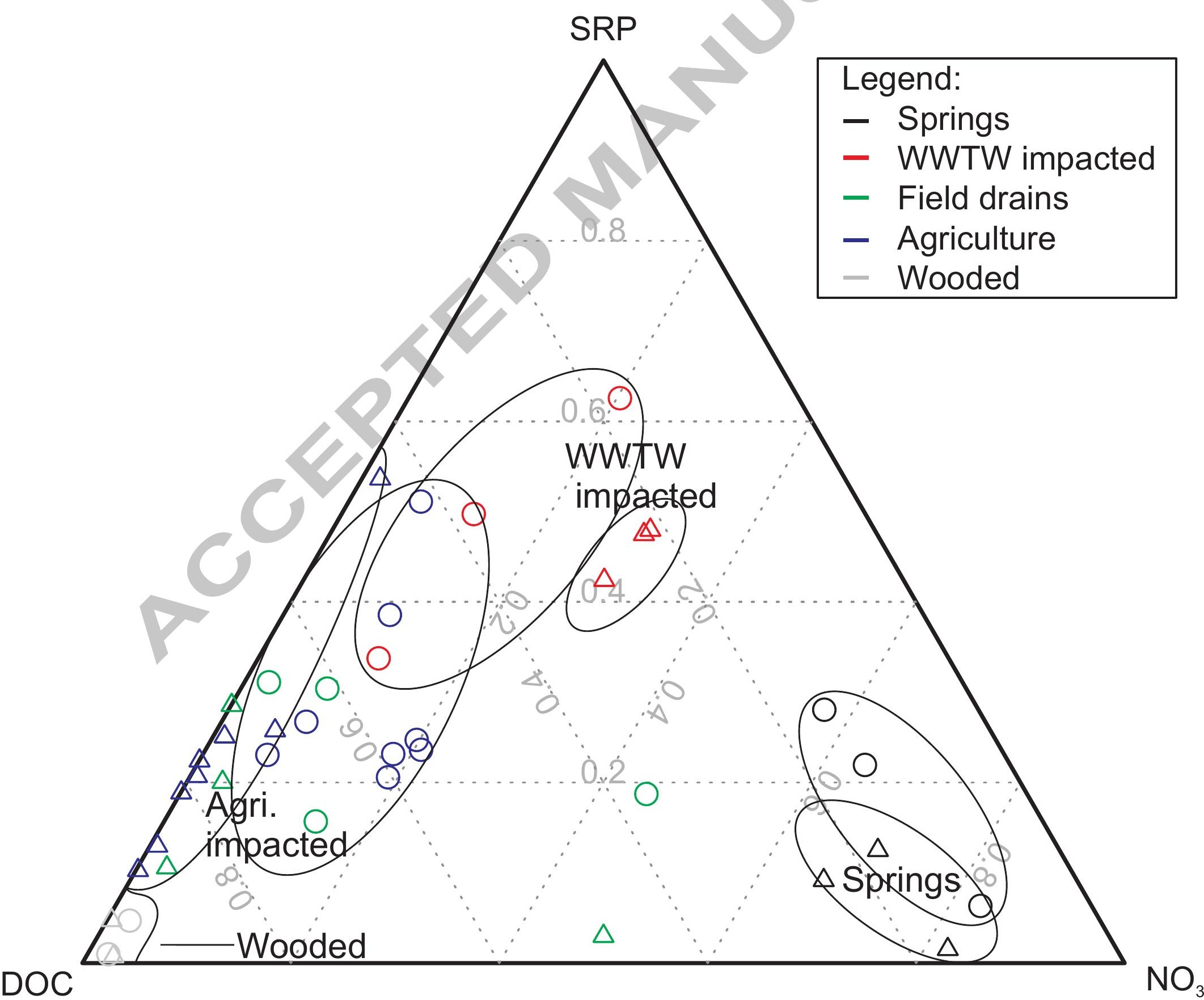




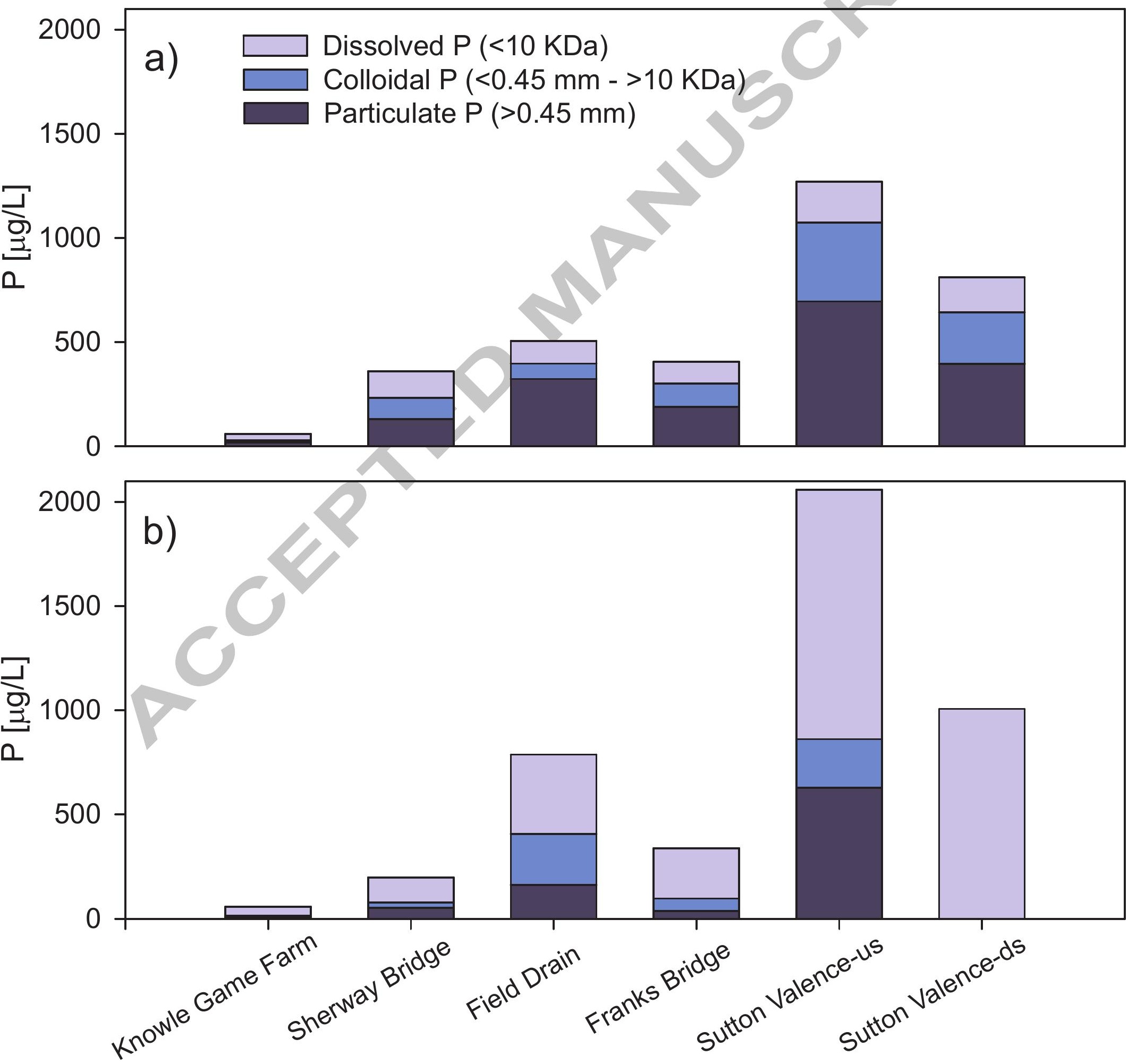


$\sqrt[\text { Figure-5 }]{\text { a) }}$

$\sqrt[\text { Figutes } 5]{\text { a) }}$

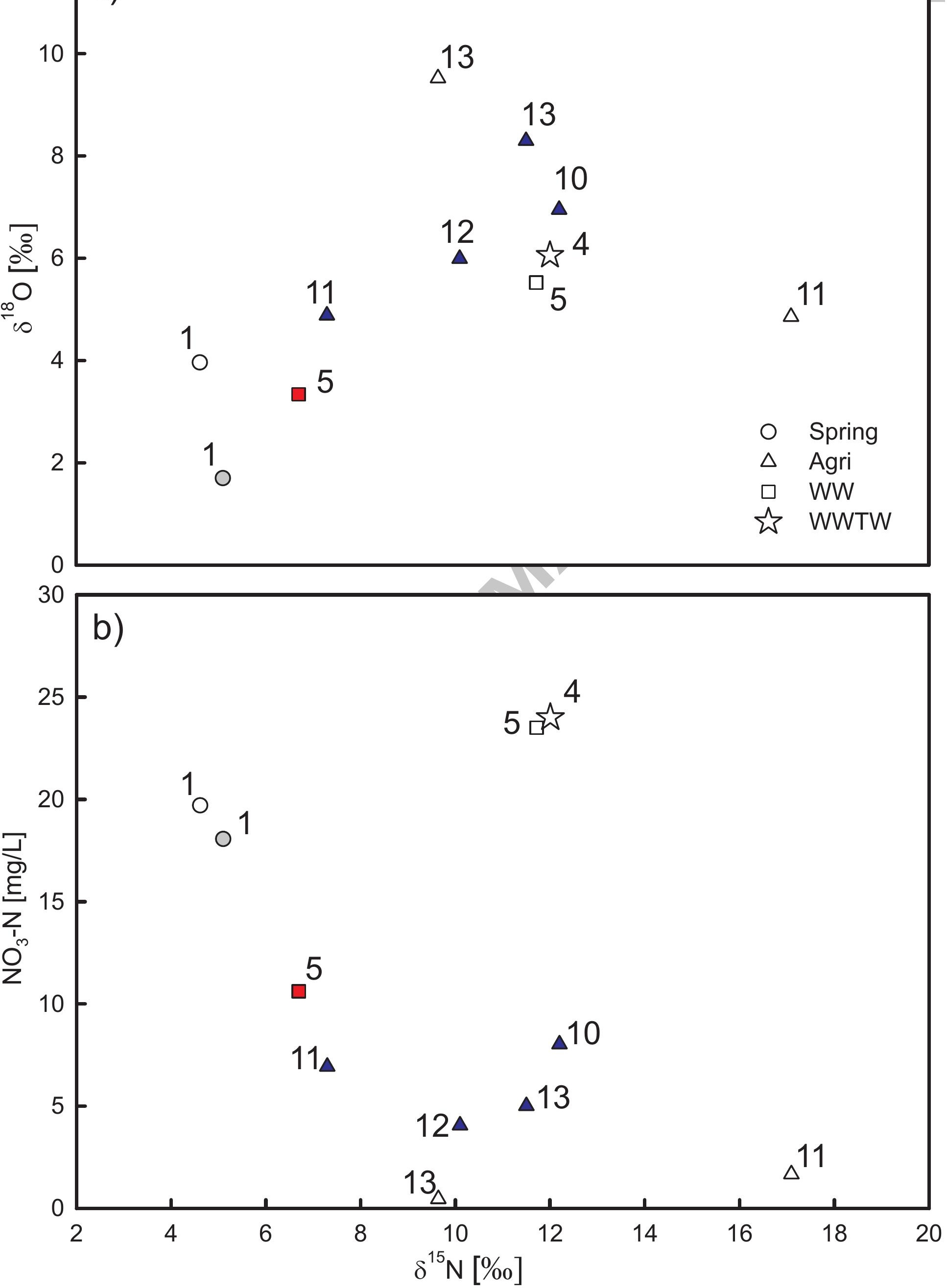

10
8

$\Delta^{13}$

3

$12 \quad i 5$

O Spring

$\triangle$ Agri

$\square$ WW

WWTW

b)

$11 \triangle$

$\Delta$

$\delta^{15} \mathrm{~N}[\% 0]$ 
Table 1.

\begin{tabular}{|c|c|c|c|c|c|c|c|c|c|c|c|c|c|c|c|c|c|c|c|c|c|c|}
\hline $\begin{array}{l}\text { Variable } \\
\text { Unit } \\
\text { Sampling round }\end{array}$ & $\begin{array}{c}\mathrm{DOC} \\
\mathrm{mg} / \mathrm{L} \\
\mathrm{R} 1\end{array}$ & $\begin{array}{c}\mathrm{DOC} \\
\mathrm{mg} / \mathrm{L} \\
\mathrm{R} 2 \\
\end{array}$ & $\begin{array}{c}\mathrm{NO}_{3}-\mathrm{N} \\
\mathrm{mg} / \mathrm{L} \\
\mathrm{R} 1 \\
\end{array}$ & $\begin{array}{c}\mathrm{NO}_{3}-\mathrm{N} \\
\mathrm{mg} / \mathrm{L} \\
\mathrm{R} 2 \\
\end{array}$ & $\begin{array}{c}\mathrm{TDP} \\
\mu \mathrm{g} / \mathrm{L} \\
\mathrm{R} 1 \\
\end{array}$ & $\begin{array}{c}\mathrm{TDP} \\
\mu \mathrm{g} / \mathrm{L} \\
\mathrm{R} 2 \\
\end{array}$ & $\begin{array}{c}\mathrm{SRP} \\
\mu \mathrm{g} / \mathrm{L} \\
\mathrm{R} 1\end{array}$ & $\begin{array}{c}\mathrm{SRP} \\
\mu \mathrm{g} / \mathrm{L} \\
\mathrm{R} 2 \\
\end{array}$ & $\begin{array}{c}\text { DHP } \\
\mu \mathrm{g} / \mathrm{L} \\
\mathrm{R} 1\end{array}$ & $\begin{array}{c}\text { DHP } \\
\mu \mathrm{g} / \mathrm{L} \\
\mathrm{R} 2 \\
\end{array}$ & $\begin{array}{c}\mathrm{TP} \\
\mu \mathrm{g} / \mathrm{L} \\
\mathrm{R} 1 \\
\end{array}$ & $\begin{array}{c}\mathrm{TP} \\
\mu \mathrm{g} / \mathrm{L} \\
\mathrm{R} 2 \\
\end{array}$ & $\begin{array}{c}\mathrm{PP} \\
\mu \mathrm{g} / \mathrm{L} \\
\mathrm{R} 1\end{array}$ & $\begin{array}{c}\mathrm{PP} \\
\mu \mathrm{g} / \mathrm{L} \\
\mathrm{R} 2 \\
\end{array}$ & $\mathrm{~N}: \mathrm{P}$ & $\mathrm{N}: \mathrm{P}$ & SRP:DHP & SRP:DHP & $\begin{array}{l}\text { SRP } \\
\% \\
\text { R1 }\end{array}$ & $\begin{array}{l}\mathrm{SRP} \\
\% \\
\mathrm{R} 2 \\
\end{array}$ & $\begin{array}{l}\text { DHP } \\
\% \\
\text { R1 }\end{array}$ & $\begin{array}{l}\text { DHP } \\
\% \\
\text { R2 } \\
\end{array}$ \\
\hline \multicolumn{23}{|l|}{ Springs } \\
\hline 1 Knowle Game Farm & 1.1 & 1.0 & 20.2 & 19.7 & 42 & 31 & 13 & 9 & 29 & 22 & 60 & 45 & 18 & 14 & 3437 & 4853 & 0.4 & 0.4 & 31 & 29 & 69 & 71 \\
\hline 2 Hollis Farm & 1.2 & 1.3 & 13.2 & 13.3 & 41 & 48 & 38 & 45 & $<7$ & 3 & 47 & N/A & $<7$ & N/A & 766 & 654 & 12.7 & 15.0 & 93 & 94 & 7 & 6 \\
\hline 3 Pope Hall & 1.5 & 0.8 & 13.8 & 12.5 & 84 & 56 & 57 & 55 & 27 & 1 & 85 & N/A & $<7$ & N/A & 534 & 505 & 2.1 & 55.0 & 68 & 98 & 32 & 2 \\
\hline Mean & 1.3 & 1.0 & 15.7 & 15.2 & 56 & 45 & 36 & 36 & 28 & 8.7 & 64 & 45 & 18 & 14 & 1579 & 2004 & 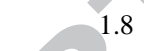 & 2.8 & 64 & 74 & 36 & 26 \\
\hline \multicolumn{23}{|l|}{ WWTW discharge } \\
\hline 4 Sutton Valence & 3.5 & 4.4 & 10.0 & 24.0 & 266 & 1004 & 260 & 928 & $<7$ & 76 & 276 & 992 & 10 & $<7$ & 85 & 57 & 43.3 & 12.2 & 98 & 92 & 2 & 8 \\
\hline \multicolumn{23}{|l|}{ WWTW impacted rivers } \\
\hline 5 Sutton Valence-ds & 13.0 & 4.5 & 10.6 & 23.5 & 415 & 1000 & 349 & 912 & 66 & 92 & 810 & 1006 & 395 & $<7$ & 67 & 57 & 5.3 & 10.4 & 84 & 91 & 16 & 9 \\
\hline 6 Biddenden-ds & 13.9 & 9.1 & 7.1 & 35.1 & 207 & 1344 & 174 & 1268 & 33 & 76 & 330 & N/A & 123 & N/A & 90 & 61 & 5.3 & 16.7 & 84 & 94 & 16 & 6 \\
\hline Mean & 13.5 & 6.8 & 8.8 & 29.3 & 311 & 1172 & 262 & 1090 & 49.5 & 84 & 570 & 1006 & 259 & $<7$ & 78 & 59 & 5.3 & 12.8 & 84 & 93 & 16 & 7 \\
\hline \multicolumn{23}{|l|}{ Field drains } \\
\hline 7 Southernden & 16.4 & 4.7 & 5.3 & 0.8 & 247 & 144 & 165 & 117 & 82 & 27 & 424 & N/A & 177 & N/A & 72 & 15 & 2.0 & 4.3 & 67 & 81 & 33 & 19 \\
\hline 8 Little Southernden & 17.3 & 13.4 & 51.0 & 51.6 & 242 & 101 & 180 & 78 & 62 & 23 & 426 & 170 & 184 & 69 & 627 & 1463 & 2.9 & 3.4 & 74 & 77 & 26 & 23 \\
\hline 9 Broken Bridge & 21.2 & 7.7 & 1.8 & 1.0 & 281 & 142 & 201 & 89 & 80 & 53 & 436 & N/A & 155 & N/A & 20 & 24 & 2.5 & 1.7 & 72 & 63 & 28 & 37 \\
\hline 10 Field Drain & 16.0 & 14 & 8.0 & 0.03 & 183 & 626 & 73 & 530 & 110 & 96 & 506 & 788 & 323 & 162 & 243 & 0.1 & 0.7 & 5.5 & 40 & 85 & 60 & 15 \\
\hline Mean & 17.7 & 10 & 16.5 & 13.4 & 238 & 253 & 155 & 203.5 & 83.5 & 50 & 448 & 479 & 210 & 116 & 240 & 376 & 1.7 & 3.2 & 63 & 76 & 37 & 24 \\
\hline \multicolumn{23}{|c|}{ Agriculturally impacted rivers* } \\
\hline 11 Sutton Valence-us & 17.4 & 11.0 & 6.9 & 1.7 & 575 & 1432 & 430 & 1252 & 145 & 180 & 1270 & 2060 & 695 & 628 & 35 & 3 & 3.0 & 7.0 & 75 & 87 & 25 & 13 \\
\hline 12 Sherway Bridge & 19.2 & 7.5 & 4.1 & 0.2 & 229 & 145 & 127 & 106 & 102 & 39 & 360 & 198 & 131 & 53 & 71 & 5 & 1.2 & 2.7 & 55 & 73 & 45 & 27 \\
\hline 13 Franks Bridge & 16.7 & 8.0 & 5.0 & 0.5 & 217 & 301 & 139 & 256 & 78 & 45 & 406 & 339 & 189 & 38 & 80 & 4 & 1.8 & 5.7 & 64 & 85 & 36 & 15 \\
\hline 14 Romden Castle & 12.3 & 10.4 & 10.5 & 0.3 & 137 & 297 & 111 & 259 & 26 & 38 & 698 & N/A & 561 & N/A & 209 & 3 & 4.3 & 6.8 & 81 & 87 & 19 & 13 \\
\hline 15Snapmill & 12.2 & 11.6 & 10.9 & 0.1 & 130 & 320 & 105 & 126 & 25 & 194 & 867 & N/A & 737 & N/A & 230 & 2 & 4.2 & 0.6 & 81 & 39 & 19 & 61 \\
\hline 16 Stanford Bridge & 12.6 & 12.4 & 9.4 & 0.02 & 131 & 499 & 101 & 339 & 30 & 160 & 570 & N/A & 439 & N/A & 207 & 0.2 & 3.4 & 2.1 & 77 & 68 & 23 & 32 \\
\hline 17 Snoadhill Farm & 14.9 & 15.8 & 11.3 & 0.04 & 132 & 404 & 103 & & 29 & 56 & 510 & N/A & 378 & N/A & 243 & 0.2 & 3.6 & 6.2 & 78 & 86 & 22 & 14 \\
\hline 18 Little Ommerden & 18.0 & 8.7 & 8.6 & 2.8 & 283 & 342 & 275 & & 8 & 32 & 429 & N/A & 146 & N/A & 70 & 20 & 34.4 & 9.7 & 97 & 91 & 3 & 9 \\
\hline Mean & 15.4 & 10.7 & 8.3 & 0.7 & 229 & 468 & & & 55 & 93 & 639 & 866 & 410 & 240 & 143 & 5 & 3.2 & 3.4 & 76 & 77 & 24 & 23 \\
\hline \multicolumn{23}{|l|}{ Wooded catchment } \\
\hline 19 Rogley Hill & 11.7 & 4.9 & 0.7 & 0.1 & 34 & 32 & & 23 & 22 & 9 & 218 & N/A & 184 & N/A & 122 & 8 & 0.5 & 2.6 & 35 & 72 & 65 & 28 \\
\hline 20 Chittenden wood & 17.0 & 4.9 & 0.8 & 0.5 & 10 & 10 & $<7$ & 3.5 & $<7$ & 6.5 & 24 & N/A & 14 & N/A & 533 & 323 & 0.5 & 0.5 & 35 & 35 & 65 & 65 \\
\hline Mean & 14.4 & 4.9 & 0.8 & 0.3 & 22 & 21 & 12 & 13.25 & 22 & 7.75 & 121 & N/A & 99 & N/A & 327 & 165 & 0.5 & 1.1 & 35 & 53 & 65 & 47 \\
\hline
\end{tabular}

R1=High flow conditions, R2=Baseflow conditions, *predominantly agricultural with limited WW inputs, N:P are NO3:SRP (molar ratios). 
Table 1 continued

Variable $\quad \mathrm{NO}_{3}-\mathrm{N}: \mathrm{Cl} \quad \mathrm{NO}_{3}-\mathrm{N}: \mathrm{Cl} \quad$ TDP:Cl $\quad$ TDP:Cl $\quad$ SRP:Cl $\quad$ SRP:Cl

\begin{tabular}{|c|c|c|c|c|c|c|}
\hline Sampling round & $\mathrm{R} 1$ & $\mathrm{R} 2$ & $\mathrm{R} 1$ & $\mathrm{R} 2$ & $\mathrm{R} 1$ & $\mathrm{R} 2$ \\
\hline \multicolumn{7}{|l|}{ Springs } \\
\hline 1 Knowle Game Farm & 0.834 & 0.851 & 0.002 & 0.001 & 0.001 & 0.000 \\
\hline 2 Hollis Farm & 0.400 & 0.439 & 0.001 & 0.002 & 0.001 & 0.001 \\
\hline 3 Pope Hall & 0.508 & 0.445 & 0.003 & 0.002 & 0.002 & 0.002 \\
\hline Mean & 0.560 & 0.558 & 0.002 & 0.002 & 0.001 & 0.001 \\
\hline \multicolumn{7}{|l|}{ WWTW discharge } \\
\hline 4 Sutton Valence & NA & 0.270 & NA & 0.011 & NA & 0.010 \\
\hline \multicolumn{7}{|l|}{$W W T W$ impacted rivers } \\
\hline 5 Sutton Valence-ds & 0.214 & 0.266 & 0.008 & 0.011 & 0.007 & 0.010 \\
\hline 6 Biddenden-ds & 0.142 & 0.280 & 0.004 & 0.011 & 0.004 & 0.010 \\
\hline Mean & 0.178 & 0.274 & 0.006 & 0.011 & 0.005 & 0.010 \\
\hline \multicolumn{7}{|l|}{ Field drains } \\
\hline 7 Southernden & 0.183 & 0.024 & 0.008 & 0.004 & 0.006 & 0.003 \\
\hline 8 Little Southernden & 1.747 & 1.088 & 0.008 & 0.002 & 0.006 & 0.002 \\
\hline 9 Broken Bridge & 0.062 & 0.016 & 0.010 & 0.002 & 0.007 & 0.002 \\
\hline 10 Field Drain & 0.206 & 0.001 & 0.005 & 0.018 & 0.002 & 0.016 \\
\hline Mean & 0.524 & 0.307 & 0.008 & 0.006 & 0.005 & 0.005 \\
\hline \multicolumn{7}{|c|}{ Agriculturally impacted rivers* } \\
\hline 11 Sutton Valence-us & 0.153 & 0.032 & 0.013 & 0.027 & 0.010 & 0.024 \\
\hline 12 Sherway Bridge & 0.105 & 0.005 & 0.006 & 0.003 & 0.003 & 0.002 \\
\hline 13 Franks Bridge & 0.135 & 0.011 & 0.006 & 0.007 & 0.004 & 0.006 \\
\hline 14 Romden Castle & 0.292 & 0.005 & 0.004 & 0.004 & 0.003 & 0.004 \\
\hline 15 Snapmill & 0.274 & 0.001 & 0.003 & 0.005 & 0.003 & 0.002 \\
\hline 16 Stanford Bridge & 0.264 & 0.000 & 0.004 & 0.005 & 0.003 & 0.004 \\
\hline 17 Snoadhill Farm & 0.278 & 0.001 & 0.003 & 0.007 & 0.003 & 0.006 \\
\hline 18 Little Ommerden & 0.304 & 0.020 & 0.010 & 0.002 & 0.010 & 0.002 \\
\hline Mean & 0.222 & 0.010 & 0.006 & 0.007 & 0.005 & 0.005 \\
\hline \multicolumn{7}{|l|}{ Wooded catchment } \\
\hline 19 Rogley Hill & 0.022 & 0.002 & 0.001 & 0.001 & 0.000 & 0.000 \\
\hline 20 Chittenden wood & 0.022 & 0.012 & 0.000 & 0.000 & NA & 0.000 \\
\hline Mean & 0.022 & 0.006 & 0.001 & 0.000 & 0.000 & 0.000 \\
\hline
\end{tabular}


Table 2.

\begin{tabular}{lll} 
Variable & Source $^{\mathrm{a}}$ & Round $^{\mathrm{b}}$ \\
\hline $\mathrm{pH}$ & $0.00084 * * *$ & $0.01088 *$ \\
$\mathrm{SEC}$ & $1.0 \mathrm{e}-11 * * *$ & $3.7 \mathrm{e}-09 * * *$ \\
$\mathrm{HCO}_{3}$ & $3.3 \mathrm{e}-06 * * *$ & $1.8 \mathrm{e}-05 * * *$ \\
$\mathrm{SO}_{4}$ & $9.9 \mathrm{e}-05 * * *$ & 0.52 \\
$\mathrm{Cl}$ & $2.6 \mathrm{e}-06 * * *$ & $2.0 \mathrm{e}-05 * * *$ \\
$\mathrm{DOC}$ & $3.4 \mathrm{e}-15 * * *$ & $6.4 \mathrm{e}-05 * * *$ \\
$\mathrm{NO}_{3}$ & $0.0011 * *$ & $0.0013 * *$ \\
$\mathrm{TDP}$ & $0.00067 * * *$ & $0.01225 *$ \\
$\mathrm{SRP}$ & $0.00046 * * *$ & $0.00951 * *$ \\
$\mathrm{DHP}$ & $0.029 *$ & 0.361 \\
$\mathrm{NO} 3: \mathrm{SRP}$ & $0.00056 * * *$ & $0.00044 * * *$
\end{tabular}

${ }^{\mathrm{a}}$ Grouped according to source type (see Table 1 ).

${ }^{\mathrm{b}}$ Grouped by sampling occasions R1 and R2

Significance denoted as follow: $0 * * * 0.001 * * 0.01 * 0.05$

Table 3.

\begin{tabular}{lcccccccccccccccc} 
Variable & DP & DP & FA & FA & TRP & TRP & TY & TY & FI & FI & $\beta / \alpha$ & $\beta / \alpha$ & HI & HI & TRP:FA & TRP:FA \\
Unit & $\mu \mathrm{g} / \mathrm{L}$ & $\mu \mathrm{g} / \mathrm{L}$ & R.U & R.U & R.U & R.U & R.U & R.U & & & & & & & & \\
Sampling round & R1 & R2 & R1 & R2 & R1 & R2 & R1 & R2 & R1 & R2 & R1 & R2 & R1 & R2 & R1 & R2 \\
\hline 1. Knowle Game Farm & 31 & 44 & 0.1 & 0.1 & 0.18 & 0.20 & 0.09 & 0.26 & 1.59 & 1.62 & 0.68 & 0.71 & 1.55 & 1.48 & 1.77 & 1.66 \\
5. Sutton Valence-ds & 166 & 1004 & 12.6 & 1.7 & 3.33 & 0.66 & 0.99 & 0.25 & 1.60 & 1.60 & 0.57 & 0.79 & 17.62 & 8.96 & 0.26 & 0.38 \\
10. Field Drain & 109 & 381 & 15.9 & 3.3 & 3.31 & 0.95 & 0.98 & 0.31 & 1.45 & 1.53 & 0.56 & 0.53 & 21.08 & 15.67 & 0.21 & 0.29 \\
11. Sutton Valence-us & 196 & 1198 & 10.4 & 2.7 & 2.45 & 0.90 & 0.80 & 0.25 & 1.54 & 1.61 & 0.59 & 0.64 & 19.16 & 12.74 & 0.24 & 0.34 \\
12. Sherway Bridge & 129 & 121 & 17.0 & 1.6 & 3.54 & 0.48 & 0.85 & 0.25 & 1.60 & 1.51 & 0.57 & 0.59 & 20.02 & 11.46 & 0.21 & 0.31 \\
13. Franks Bridge & 105 & 242 & 15.8 & 1.7 & 3.33 & 0.59 & 0.82 & 0.26 & 1.54 & 1.70 & 0.56 & 0.57 & 21.21 & 12.24 & 0.21 & 0.34 \\
\hline
\end{tabular}

$\mathrm{DP}=$ 'truly' dissolved $\mathrm{P}(<10 \mathrm{Kda}), \mathrm{RU}=$ Raman Unit, fluorescence indices (see section 3.3.3 for full explanations): $\mathrm{FA}=\mathrm{Fulvic}$ acid, TRP=Tryptophan,

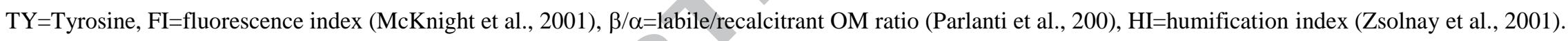


Multi technique approach to understand $\mathrm{C}, \mathrm{N}$ and $\mathrm{P}$ within catchment processes

Changes in nutrient stoichiometry/bioavailability under contrasting flow conditions

$\mathrm{N}$ and $\mathrm{O}$ isotopes show dominance of waste water (WW) inputs during baseflow

Fluorescence DOM indices characterise WW inputs to rivers

Grid-to-Grid distributed model used to assess spatial variations in nutrient flux 